\title{
Nature conservation in a digitalized world: echo chambers and filter bubbles
}

\author{
$\underline{\text { Annika Miller }}^{1}, \underline{\text { Saskia Arndt }}^{1}$, Lina Engel $^{1}$ and $^{\text {Nathalie Boot }}{ }^{1}$
}

\begin{abstract}
Digital echo chambers and filter bubbles are increasingly the subject of societal, political, and scientific discourse. However, the impact of these phenomena on nature conservation remains understudied. This study provides an explorative overview of the potential relevance of digital echo chambers and filter bubbles for nature conservation practice. For this purpose, data collected during a literature review as well as a digital expert survey of German conservation actors was evaluated. The data show that the phenomena are already considered in conjunction with conservation topics with a focus on climate protection in the scientific literature and nature conservation practice to a small but increasing extent. Furthermore, it is recognized that they pose more risks than potential benefits for nature conservation communication. However, the understanding of the exact processes associated with digital echo chambers and filter bubbles is insufficient. The study also identified an extensive need for action and research regarding the strategic consideration and handling of digital echo chambers and filter bubbles in nature conservation practice. There is significant potential to improve the societal acceptance upon which nature conservation depends and to increase the public participation in nature conservation issues. To make a responsible and effective contribution to society, nature conservation must keep abreast of new communication factors that are emerging in the age of digitalization.
\end{abstract}

Key Words: climate protection; digitalization; echo chamber; filter bubble; nature conservation; online communication

\section{INTRODUCTION}

In this digital era, characterized by increasing online communication, the Internet offers an ever-expanding plethora of information and opinions. In recent years, nature conservation has recognized this potential of new media as a communication channel and its role in shaping public opinion. Although communication with the public received little attention in nature conservation until the early 1990 s, it is of fundamental importance (Adomßent 2005). This is because conservation issues can only gain societal relevance and acceptance through communication (Heiland 1999, Brendle 2002, Adomßent 2005). Thus, the realization of conservation goals depends largely on engagement and cooperation with the public (Heiland 1999, Adomßent 2005, Eser 2016). In recent history, conservation has therefore increasingly used current media platforms to communicate with society and by the early 1990s, the Internet joined its communication repertoire (Hindmarsh and Calibeo 2017). This new technology offered diverse new opportunities for exchange of information, participation, interaction, and opinion building, and thus quickly transformed societal and nature conservation communication (Büscher 2016). Peters et al. (2005) accordingly label communication via the Internet as a standard component of good conservation practice.

However, the potential of the Internet as a diverse source of information and a tool for dialogue about conservation topics is often limited as users tend to remain in a familiar digital environment that corresponds to their personal worldview (Sunstein 2001, cf. Adamic and Glance 2005). So-called digital echo chambers and filter bubbles have the potential to amplify this phenomenon. The concept of the digital echo chamber was already addressed by Sunstein in 2001. Ten years later, Pariser introduced and discussed the filter bubble. Although both concepts have been examined in recent literature, their relevance for nature conservation practice has so far remained understudied. Therefore, the aim of this study is to create an explorative overview of the potential relevance and handling of echo chambers and filter bubbles in nature conservation practice. Because there is no universally valid definition of the term "nature conservation," this study defines it as follows: nature conservation describes the protection, maintenance, or restoration of the biological diversity, the capability, and functionality of the natural resources as well as the uniqueness, the beauty, and the recreational value of nature. Particularly the protection of biotopes, species and habitats are central aspects (German Federal Nature Conservation Act 2009 § 1).

The terms "echo chamber" and "filter bubble" have rather loose definitions and are frequently used interchangeably in public discourse (Terren and Borge-Bravo 2021). It should also be noted that the existence of echo chamber effects has been known and researched for some time, but the phenomenon has only been referred to by the term echo chamber since the beginning of the 21 st century (cf. Sunstein 2001, Stark et al. 2021). For the purposes of this study, the two terms echo chamber and filter bubble are treated as different but interrelated phenomena and defined as follows:

An echo chamber describes an environment in which a person only interacts with like-minded people, so that the encountered opinions or beliefs reflect their own (Dubois and Blank 2018). Existing views are reinforced and alternative ideas are not considered (Flaxman et al. 2016). Generally, echo chambers can exist wherever information is exchanged, whether offline or on the Internet. However, this study only considers the digital phenomenon.

The term filter bubble describes a figurative sphere in which filter algorithms personalize the content that search engines, news aggregators, and social networks provide for each individual user (Pariser 2011). Affected persons are often unaware of this and therefore consider the provided information to be neutral, objective, and true, the result of which can be a distorted 
perception of reality and a loss of information diversity (Pariser 2011). A person's awareness of such effects and their susceptibility to them depend on various factors such as geocultural context, socioeconomic circumstances, and personality (cf. Burbach et al. 2019, Sindermann et al. 2020, Tandoc et al. 2020).

To facilitate the creation of an explorative insight into the topic of echo chambers and filter bubbles in nature conservation, we aim to answer the following questions:

1. To what extent are echo chambers and filter bubbles already considered in nature conservation literature and practice?

2. What are possible effects of echo chambers and filter bubbles on nature conservation?

3. To what extent is there a need for research and action regarding the relevance of echo chambers and filter bubbles for nature conservation?

To answer these questions, the current state of research was examined through a literature review. In addition, an expert survey was conducted to assess to what extent the topic is already known and considered in nature conservation practice.

\section{METHODS}

\section{Literature review}

The systematic approach of the literature review enabled an extensive search for relevant literature, which was selected and evaluated according to predefined search strings and criteria (Denyer and Tranfield 2009, Briner and Denyer 2012). The literature review was carried out by combining key words from the field of nature conservation and the terms echo chamber or filter bubble into search strings (Appendix 1). To ensure a comprehensive review within the available resources, only literature that fulfilled the following conditions was taken into account:

- the literature mentions echo chambers and/or filter bubbles (according to the understanding of this study exclusively in a digital context) and a nature conservation-related term,

- was published after 2011, when Eli Pariser defined the term filter bubble in his book The Filter Bubble: What the Internet Is Hiding from You,

- is considered to be a scientific study or grey literature,

- is freely accessible in German or English.

The literature review was carried out in the search engine Google Scholar. The results were documented in a literature database (Appendix 2) and then categorized according to their content. The aim was to analyze to what extent each identified source deals with the topic of echo chambers and/or filter bubbles and their relevance for nature conservation. For this purpose, the categories pictured in Table 1 were defined.

\section{Expert survey}

This method was utilized to compile the insights nature conservation actors may have concerning the relevance of echo chambers and filter bubbles in their work. The expert survey was conducted by e-mail, involving nature conservation actors throughout Germany, thus providing access to a variety of legal, geographic, and academic backgrounds (Bowden and GalindoGonzalez 2015).
Table 1. Categorization of identified sources according to the described thematic relation between echo chambers and/or filter bubbles and a nature conservation topic.

\begin{tabular}{|c|c|c|c|}
\hline Category & A & B & $\mathrm{C}$ \\
\hline Description & $\begin{array}{l}\text { Echo chambers } \\
\text { and/or filter } \\
\text { bubbles and their } \\
\text { possible impact } \\
\text { on nature } \\
\text { conservation are } \\
\text { the main subject } \\
\text { of the source. }\end{array}$ & $\begin{array}{l}\text { Echo chambers } \\
\text { and/or filter } \\
\text { bubbles are } \\
\text { mentioned in a } \\
\text { context related to } \\
\text { nature } \\
\text { conservation, but } \\
\text { this connection is } \\
\text { not the main } \\
\text { subject of the } \\
\text { source. }\end{array}$ & $\begin{array}{l}\text { Echo chambers } \\
\text { and/or filter } \\
\text { bubbles are } \\
\text { mentioned in the } \\
\text { same paper as a } \\
\text { nature } \\
\text { conservation- } \\
\text { related topic, but a } \\
\text { thematic relation is } \\
\text { not evident. }\end{array}$ \\
\hline
\end{tabular}

The 232 selected actors stem from various sectors: research and teaching institutions, public authorities, registered associations, NGOs, national parks, and private corporations (foremost planning offices). Additionally, whenever possible, persons with a position linked to digital media, i.e., press officers, were selected. The survey form included an introductory text, an explanation of the terms echo chamber and filter bubble, as well as the survey questions (Appendix 3). To increase the response rate, the survey was kept short, including mainly multiple choice questions. More thorough responses were possible through a follow-up comment after each question.

The thematic analysis approach according to Braun and Clarke (2012) was utilized to evaluate the survey data. In this context, the qualitative survey answers were closely examined, coded, and consequential themes were derived (Fig. 1 and Appendix 4). First, all responses recorded through the expert survey were split into "answer sections." An "answer section" is a sentence or phrase, i.e., part of a survey response, that contains at least one core statement. Only text sections with no relevance to the research topic remained unconsidered. If answer sections with identical or similar statements occur throughout the survey data, a pattern becomes recognizable. This pattern can then be formulated as a code, i.e., a summarizing statement. The identified codes were in turn combined into overarching themes during the last step of the thematic analysis. This process was backed by the quantitative results of the multiple-choice questions. The derived codes and themes were subsequently analyzed concerning their relevance for the research objective of this study - the creation of an explorative overview of the potential relevance of echo chambers and filter bubbles for nature conservation practice.

Fig. 1. The main steps of the thematic analysis approach (based on Braun and Clarke 2012).

\begin{tabular}{|c|c|c|c|}
\hline $\begin{array}{l}\text { 1. Divide data } \\
\text { into sections }\end{array}$ & $\begin{array}{l}\text { 2. Identify } \\
\text { patterns }\end{array}$ & $\begin{array}{l}\text { 3. Define } \\
\text { codes }\end{array}$ & $\begin{array}{l}\text { 4. Identify } \\
\text { themes }\end{array}$ \\
\hline & 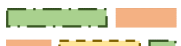 & Code A & Code $A$ \\
\hline & 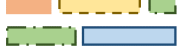 & Code B & \\
\hline & $\square$ & Code & Code B \\
\hline & ים & Code D & \\
\hline
\end{tabular}




\section{RESULTS}

To what extent are echo chambers and filter bubbles already considered in nature conservation literature and practice?

The literature review revealed that scientific literature increasingly takes echo chambers and filter bubbles as well as their relevance for various nature conservation topics into account. A total of 40 scientific sources were gathered in the literature review until midJanuary 2020 (see Appendix 2). A total of 10 sources used exclusively the term filter bubble, 18 exclusively the term echo chamber, and 12 contained both terms. In the systematic categorization of the sources according to their content, only 2 sources could be assigned to category A, 18 to category B, and 20 to category C. Nevertheless, there is a substantial increase in scientific publications on the subject from 2017 onwards (Fig. 2).

Fig. 2. Distribution of literature sources according to publication date and category allocation $(n=40, *$ until 18 January 2020).

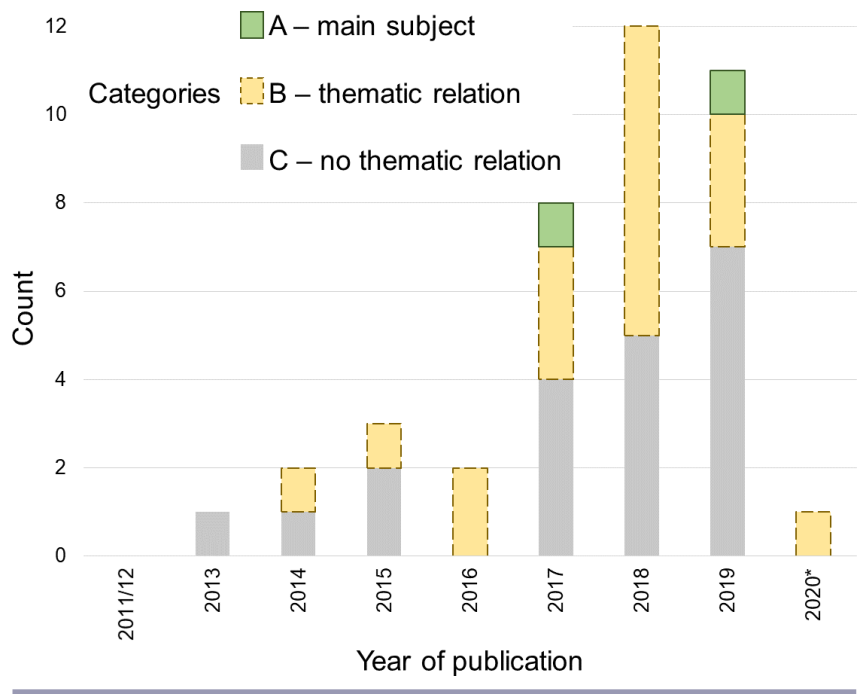

Table 2 shows the division of category A and B sources into subject areas of nature conservation. It is noticeable that the subject area "climate protection and climate change" has so far been most often scientifically investigated in connection with echo chambers and filter bubbles. Possible reasons for the focus on climate issues will be addressed in the discussion.

The results of the expert survey complement the findings from the literature review. They show that echo chambers and filter bubbles are already known to the nature conservation experts that responded to the survey, but that this awareness for the most part does not translate into concrete action.

Out of the 232 selected nature conservation experts working in Germany, 13 responded to the survey. They work in a variety of sectors, such as public environmental agencies, an environmental planning company, protected area administrations, a lobby organization, and an NGO. The multiple-choice responses depicted in Table 3 complemented the thematic analysis process. All survey answers or answer sections cited below were translated from German. The original data is available in Appendix 5.
Table 2. Grouping of category A and B sources into subject areas.

\begin{tabular}{lcl}
\hline \hline Subject area & Count & Sources \\
\hline $\begin{array}{l}\text { Climate protection } \\
\text { and climate change }\end{array}$ & 9 & $\begin{array}{l}\text { Elshof 2015, Hartl and Ramsauer 2017, } \\
\text { Clermont 2018, Hermwille and Siemons } \\
\text { 2018, Paulo 2018, Walter et al. 2018, } \\
\text { Zegers 2018, Colston and Thomas 2019, } \\
\text { Jasny and Fisher 2019 }\end{array}$ \\
$\begin{array}{l}\text { Nature and } \\
\text { environmental } \\
\text { conservation } \\
\text { communication }\end{array}$ & 5 & $\begin{array}{l}\text { Hölderle 2016, Pilkington 2016, Fraser } \\
\text { and Fraser 2017, Cố and Darling 2018, } \\
\begin{array}{l}\text { Environmental } \\
\text { management }\end{array}\end{array}$ \\
$\begin{array}{l}\text { Species } \\
\text { conservation } \\
\text { Spatial planning }\end{array}$ & 3 & $\begin{array}{l}\text { Madzwamuse et al. 2020 } \\
\text { Ascher and Ascher 2016, Bell 2017, } \\
\text { Metson 2018 }\end{array}$ \\
\hline
\end{tabular}

Table 3. Multiple choice responses (questions and responses translated from German).

\begin{tabular}{lcc}
\hline \hline Question & Response & Count \\
\hline The terms "echo chamber" and "filter bubble" & No & 0 \\
were already familiar to me before. & Yes, the term & 3 \\
& "filter bubble" & \\
& Yes, the term & 1 \\
& "echo chamber" & \\
& Yes, both terms & 9 \\
Digital echo chambers and/or filter bubbles & No & 0 \\
may be relevant for nature conservation. & Yes & 13 \\
Digital echo chambers and/or filter bubbles & No & 6 \\
were already relevant in my professional & Yes & 6 \\
context. & No response & 1 \\
Nature conservation should take digital echo & No & 0 \\
chambers and/or filter bubbles into account in & Yes & 12 \\
its work. & No response & 1 \\
\hline
\end{tabular}

The 4 themes and 11 codes (Table 4 ) identified during the thematic analysis serve as summarizing statements of the answers to the open questions. The assignment of the individual response sections to the codes can be seen in Appendix 6. In the following, the four themes are used to provide further answers to the first research question concerning the current consideration of echo chambers and filter bubbles in nature conservation.

The first theme, "Different groups are affected by echo chambers and filter bubbles," reflects on the one hand the awareness of the responding experts that certain groups outside of nature conservation may be affected by the phenomena. For instance, one expert was concerned "when people are no longer reached with nature conservation issues/objectives because they are caught in medial filter bubbles" and others spoke of "opponents" and people with "contra" conservation opinions residing in echo chambers and filter bubbles. On the other hand, several survey participants expressed concern that they themselves may be situated in an echo chamber or filter bubble of nature conservation, mentioning "both one's own fanaticism and that of the opponents" as consequences of the phenomena. One of the experts stated that "it does not help nature conservation to solidify current facts as wisdom and to rally groups behind it that consider 
Table 4. Identified themes, codes, number of answer sections in each code, and two examples (the count does not correspond to the number of respondents because all answers were split into smaller sections, some of which were allotted to several codes).

\begin{tabular}{|c|c|c|c|}
\hline Theme & Code & $\begin{array}{l}\text { Number of sections } \\
\text { assigned to code }\end{array}$ & Example answer section \\
\hline \multirow[t]{2}{*}{$\begin{array}{l}\text { Different groups are } \\
\text { affected by echo chambers } \\
\text { and filter bubbles }\end{array}$} & $\begin{array}{l}\text { Nature conservation } \\
\text { proponents are affected by } \\
\text { echo chambers and filter } \\
\text { bubbles }\end{array}$ & 9 & $\begin{array}{l}\text { "People interested in nature conservation are also primarily } \\
\text { provided with information that they wish to read." "Both one's } \\
\text { own fanaticism and that of the opponents [can impact nature } \\
\text { conservation work]." }\end{array}$ \\
\hline & $\begin{array}{l}\text { Nature conservation } \\
\text { "adversaries" and persons } \\
\text { without a stance on nature } \\
\text { conservation are affected by } \\
\text { echo chambers and filter } \\
\text { bubbles }\end{array}$ & 6 & $\begin{array}{l}\text { "Since they can radicalize in both directions (pro and contra } \\
\text { nature conservation)." "Discussions pro and contra the } \\
\text { establishment of the national park in the social networks as } \\
\text { well." }\end{array}$ \\
\hline \multirow[t]{2}{*}{$\begin{array}{l}\text { How echo chambers and } \\
\text { filter bubbles can or cannot } \\
\text { be handled }\end{array}$} & $\begin{array}{l}\text { Echo chambers and filter } \\
\text { bubbles and their effects can } \\
\text { be deliberately utilized }\end{array}$ & 9 & $\begin{array}{l}\text { "The resulting channels can be deliberately used [by nature } \\
\text { conservation] to launch campaigns." "The public discourse on } \\
\text { nature conservation can also be influenced by targeted messages } \\
\text { using psychological methods." }\end{array}$ \\
\hline & $\begin{array}{l}\text { If and how echo chambers and } \\
\text { filter bubbles should be } \\
\text { considered in nature } \\
\text { conservation }\end{array}$ & 22 & $\begin{array}{l}\text { "Therefore, one should know the mechanisms [digital echo } \\
\text { chambers and filter bubbles], avoid them in one's own work and } \\
\text { as far as possible avoid becoming "operationally blind" oneself." } \\
\text { "IMHO in conservation discourse one should give preference to } \\
\text { open source solutions, but nevertheless also use the non-open } \\
\text { platforms to reach the general public." }\end{array}$ \\
\hline \multirow[t]{3}{*}{$\begin{array}{l}\text { Echo chambers and filter } \\
\text { bubbles are of relevance in } \\
\text { the communication of } \\
\text { nature conservation topics }\end{array}$} & $\begin{array}{l}\text { Echo chambers and filter } \\
\text { bubbles can hinder nature } \\
\text { conservation communication } \\
\text { processes and make it hard to } \\
\text { reach people }\end{array}$ & 19 & $\begin{array}{l}\text { "We have difficulties in reaching new target groups who are not } \\
\text { yet involved in nature conservation issues." "They [digital echo } \\
\text { chambers and filter bubbles] hinder consensus-oriented } \\
\text { dialogues and solutions." }\end{array}$ \\
\hline & $\begin{array}{l}\text { Echo chambers and filter } \\
\text { bubbles can reinforce views on } \\
\text { nature conservation topics }\end{array}$ & 9 & $\begin{array}{l}\text { "Opinions become more and more extreme." "On the one hand, } \\
\text { motivation and commitment can be strengthened (see Fridays } \\
\text { For Future)." }\end{array}$ \\
\hline & $\begin{array}{l}\text { There are practical examples } \\
\text { where echo chambers and } \\
\text { filter bubbles affect nature } \\
\text { conservation }\end{array}$ & 14 & $\begin{array}{l}\text { "Misinformation on the subject of infrasound." "For example, } \\
\text { pro-nature conservation reports are played up in the Google } \\
\text { ranking and thus their importance is emphasized." }\end{array}$ \\
\hline \multirow[t]{4}{*}{$\begin{array}{l}\text { Echo chambers and filter } \\
\text { bubbles are tied to different } \\
\text { societal factors }\end{array}$} & $\begin{array}{l}\text { Echo chambers and filter } \\
\text { bubbles affect all of society }\end{array}$ & 7 & $\begin{array}{l}\text { "[for nature conservation work, echo chambers and filter bubbles } \\
\text { can be] as relevant as in all areas of society." "As in every } \\
\text { emotionalized subject area, people who are interested in nature } \\
\text { conservation are also mainly supplied with information they } \\
\text { would like to read." }\end{array}$ \\
\hline & $\begin{array}{l}\text { Echo chambers and filter } \\
\text { bubbles are tied to economic } \\
\text { interests }\end{array}$ & 2 & $\begin{array}{l}\text { "The ecological impacts of electromobility are sometimes } \\
\text { deliberately not considered from a holistic perspective,"”The } \\
\text { driver for this is of course the questioning of the business model } \\
\text { of one's own company or the industry in which not only electric } \\
\text { cars, but also charging infrastructure and a lot of equipment are } \\
\text { the commercial products." }\end{array}$ \\
\hline & $\begin{array}{l}\text { Echo chambers and filter } \\
\text { bubbles are tied to political } \\
\text { interests }\end{array}$ & 3 & $\begin{array}{l}\text { "Filter bubbles or digital echo chambers are relevant for all } \\
\text { social issues, because opinions can be generated automatically } \\
\text { with the help of algorithms, as described here at the beginning. } \\
\text { A good example is the success of Cambridge Analytica." } \\
\text { "People who are interested in nature conservation are also } \\
\text { mainly supplied with information they would like to read. This is } \\
\text { of particular benefit to commercially or politically interested } \\
\text { groups." }\end{array}$ \\
\hline & $\begin{array}{l}\text { Echo chambers and filter } \\
\text { bubbles are tied to } \\
\text { technological and digital } \\
\text { factors }\end{array}$ & 14 & $\begin{array}{l}\text { "In the social media of this industry, messages for clean } \\
\text { electromobility are therefore deliberately spread, and critical } \\
\text { messages are not shared on, e.g., Twitter. Algorithms reinforce } \\
\text { this path, which results in classic filter bubbles, as algorithms } \\
\text { place information in their own online networks that corresponds } \\
\text { to this opinion." "In the exchange with like-minded people in } \\
\text { forums, on blogs, and other social channels, the own opinion is } \\
\text { strengthened." }\end{array}$ \\
\hline
\end{tabular}


this fact as ultimate and can no longer be convinced otherwise." The consideration of echo chambers and filter bubbles in nature conservation practice thus extends to their occurrence both outside and inside the nature conservation community.

The second theme was named "How echo chambers and filter bubbles can or cannot be handled." Although the active handling of the phenomena by nature conservation was the subject of the survey questions, their deliberate utilization was not. The frequent mention of the latter by the survey participants demonstrates that their consideration of the phenomena comprises a worry of active manipulation in addition to (ostensibly) inadvertent consequences of echo chambers and filter bubbles. The experts expressed concern about uses such as "influencing public opinion," opinions being "generated automatically using algorithms," or reinforcing peoples' perception of reality by steering their thoughts through "an automated algorithm or emotionalized group dynamics in social networks." Some answers even accused ostensibly proenvironment actors of these behaviors, for example when "the ecological consequences of electric mobility are sometimes deliberately not considered from a holistic perspective." At the same time, most of the experts were unable to report specific actions that are or could be taken to actively consider echo chambers and filter bubbles in nature conservation practice. This fact will be examined in more detail when answering the third research question regarding the identified need for research and action.

The third theme and its 42 answer sections show that "Echo chambers and filter bubbles are of relevance in the communication of nature conservation topics." All of the potential impacts of echo chambers and filter bubbles on nature conservation will be covered in depth in regard to the second research question. In the context of this third theme, it should be mentioned that although all respondents consider the phenomena to be relevant to nature conservation in general, only half of the experts believe that they have already played a role in their own work (Table 3). Once again it is evident that the consideration of the phenomena in conservation practice usually does not go beyond theoretical considerations and does not extend to practical measures and one's own work. We will address this in further detail in our answer to the third research question on the needs for research and action.

The answer sections assigned to the fourth theme "Echo chambers and filter bubbles are tied to different societal factors" concern the relationship of the phenomena with other parts of society. It shows that the consideration of the phenomena by conservation actors goes beyond their relevance for environmental topics. Several of the experts even consider echo chambers and filter bubbles to be as relevant for conservation "as in all areas of society" and "as in any emotionalized subject area." According to the survey participants, the phenomena also connect to economic, political, technological, and other societal factors. They mentioned, for example, the relevance and use for "commercially or politically interested groups" and "democratic processes, as in the example of Cambridge Analytica." Another strong focal point in the considerations about the phenomena seemed to be technological and media topics, such as "forums, blogs and other social channels," "false facts about climate change being disseminated en masse in social media" and society's lack of "sovereignty (control, influence) over algorithms on the Internet."

In summary, it can be said that the consideration of echo chambers and filter bubbles in conservation practice mainly covers their possible effects and connections to other societal areas but lacks concrete approaches for action. Furthermore, although all survey respondents indicated that they already knew at least one of the two terms echo chamber and filter bubble, their further answers revealed that the understanding of the phenomena is not homogeneous, even though definitions of the terms were provided with the survey form. One respondent wrote that the "terms are both very diffuse and not clearly defined."

Inconsistencies regarding the use of both terms can also be found in the identified scientific literature. Definitions of the two terms can be found in all sources of categories A and B, except for Paulo (2018), Jasny and Fisher (2019), as well as Titeca and Edmond (2019), which do not explain what is generally understood by the term echo chamber. In contrast, the term filter bubble is defined in all category A and B sources in which it occurs. In addition, the definition of echo chambers by Walter et al. (2018) lacks a differentiation between the two phenomena. Without mentioning the term filter bubble itself, Walter et al. (2018:3) describe how filter bubble mechanisms - "algorithms designed to match content with people's pre-existing opinions and preferences"- as defined by Pariser (2011) can contribute to echo chambers. Furthermore, Hölderle (2016) provides a definition of filter bubbles, which instead describes echo chambers as defined by this and other studies (e.g., Farrell 2015, Cota et al. 2019). The evidently inconsistent understanding and incorrect use of the terms in nature conservation literature and practice results in a need for research and action in this area.

\section{What are possible effects of echo chambers and filter bubbles on nature conservation?}

The results of the literature review and the expert survey show that echo chambers and filter bubbles can have a variety of effects on nature conservation. The first identified survey theme, "Different groups are affected by echo chambers and filter bubbles," was confirmed by the identified literature (cf. Clermont 2018, Paulo 2018, Colston and Thomas 2019, Titeca and Edmond 2019). In this context, the surveyed experts identified three groups: nature conservation proponents, nature conservation adversaries, and persons without a stance on nature conservation. As the following results of the survey and literature review show, their affliction by the phenomena can influence how society views and interacts with nature conservation as well as the quality of communication and work in nature conservation.

On the one hand, the survey respondents pointed out that echo chambers and filter bubbles make it difficult to reach people without an attitude toward nature conservation or engage them. On the other hand, nature conservation "opponents" can be subject to polarization, which can worsen their opinion on nature conservation. According to one survey expert, this process is promoted if only interested parties are addressed with educational efforts and supplied with nature conservation information, e.g. during participation campaigns. In addition to polarization, echo chambers and filter bubbles can reinforce processes of politicization, ideologization, and postfactual thinking (Paulo 2018). The survey respondents stated that the named effects 
particularly concern emotionally charged issues and hinder attempts of nature conservation actors to communicate with nature conservation opponents. For instance, one expert criticized the lack of factual exchange with a strongly polarized group opposing the reintroduction of the wolf in Germany.

If the above-mentioned effects of echo chambers and filter bubbles are particularly strong, they can lead to the emergence of anti-scientific movements that propagate disinformation, e.g., in the field of climate protection (Paulo 2018, Colston and Thomas 2019). Although false information may be distributed unintentionally by faulty scientific models or decontextualization of scientific evidence, it can also be deliberately caused by targeted campaigns (Colston and Thomas 2019). This was also pointed out by one of the surveyed experts, who stated that "targeted messages using psychological methods can also influence public discourse on nature conservation, e.g., by spreading false facts about climate change en masse in social media." It is particularly aggravating for nature conservation work when mis- or disinformation influences the public discourse on nature conservation topics (Metson 2018, Paulo 2018, Colston and Thomas 2019). This is underlined, for example, by Jasny and Fisher (2019), who address changes in existing echo chambers of the U.S.-climate-policy-network after Donald Trump became President. The thematic focus of the political echo chambers shifted to the question of whether climate change is humaninduced or not, a consequence of the opinions and policies expressed by Trump on climate change (Jasny and Fisher 2019). This change in thematic focus forced nature conservation to react accordingly, e.g., with climate science information campaigns (Jasny and Fisher 2019), illustrating how the affliction of other societal groups by echo chambers can have an indirect impact on nature conservation work.

In addition to the consequences for nature conservation outlined above, when uninterested citizens or conservation adversaries are located in echo chambers and filter bubbles, it can be just as damaging for nature conservation proponents to be affected by the phenomena. In this context, one expert stated: "We tend to prefer information that is consistent with our own point of view. Counterarguments are hardly allowed." A possible consequence of this one-sided information procurement was addressed by the survey respondents and is summarized by the code "Echo chambers and filter bubbles can reinforce views on nature conservation topics." Some of the experts argue that this effect can even contribute to fanaticism or radicalization of nature conservation proponents, just as it does with nature conservation adversaries.

The described reinforcement of views held by nature conservation actors in echo chambers or filter bubbles may also hinder their communication with society. One respondent warned that being in an echo chamber or filter bubble may lead to "misconceptions about the effect of arguments" among people with different views on nature conservation. On the one hand, this can lead to conflicts with related fields like climate protection. In this context, "nature conservation blocking the construction of wind parks" is one of the examples named in the expert survey. On the other hand, several of the surveyed experts mentioned difficulties in reaching conservation adversaries as well as new target groups who are not yet involved in nature conservation as a result. As one respondent points out, communication issues like these may impact the "social acceptance on which nature conservation depends."

All things considered, the code "Echo chambers and filter bubbles can hinder nature conservation communication processes and make it hard to reach people" seems to apply regardless of who is affected by the phenomena. In addition to communication problems with society, nature conservation actors may have a distorted picture of reality when they are affected by echo chambers and filter bubbles. Coupled with an unawareness of their situation, which several survey respondents warned against, this skewed view of reality can result in an inability to act effectively. A practical example identified in the literature review describes how in the Democratic Republic of Congo wrong decisions are made on the issue of poaching control because decision makers create their own echo chambers (Titeca and Edmond 2019). As a result, local dynamics and practical conservation actors are less involved and ineffective or counterproductive measures against poaching are selected (Titeca and Edmond 2019). Another study describes how echo chambers and filter bubbles influence decision makers' intake of information on biodiversity science (Clermont 2018). This affects their choices to either protect or further threaten fragile or endangered ecosystems and species, which creates two camps among decision makers in an "economy versus environment" conflict (Clermont 2018). These cases illustrate how nature conservation actors in echo chambers and filter bubbles may not receive or consider important information that could improve their work, leading to a loss of effectiveness of nature conservation.

However, the effects of echo chambers and filter bubbles may also produce beneficial outcomes for nature conservation. Two survey respondents specifically mentioned that the reinforcement of nature conservation views described above may lead to an "increased motivation and engagement" among conservation proponents, e.g., in the case of the Fridays For Future movement. Additionally, a number of studies and experts addressed the active utilization of echo chambers and filter bubbles by nature conservation.

\section{To what extent is there a need for research and action regarding the relevance of echo chambers and filter bubbles for nature conservation?}

A close analysis of the survey answers with regard to the first research question revealed that the understanding of the terms echo chamber and filter bubble among the experts is inconsistent and often unclear. Inconsistencies regarding the use of both terms can also be found in the identified scientific literature. At the same time, the survey respondents frequently stated that nature conservation actors should have an awareness of the phenomena, which arguably cannot be created without a proper, uniform understanding of the terms. Therefore, action and research are required to create and disseminate an improved terminological basis, comprehension and awareness of the phenomena, and their effects. In this context, implementing some of the expert suggestions like "training of the own people" and reminding oneself "to obtain information not only unilaterally" could be beneficial.

Moreover, although almost all experts were in favor of taking the phenomena into account in nature conservation work (Table 3) 
and the code "If and how echo chambers and filter bubbles should be considered in nature conservation" contains 22 answer sections, most respondents were unable to formulate specific, comprehensive actions to be taken. Additionally, only half of the experts thought that echo chambers and filter bubbles were previously relevant for their own work. Some of them also showed great uncertainty concerning the question of how they could consider the phenomena in their daily work. One stated "I just do not see that I could or wanted to consciously incorporate them into my work" and another questioned "whether nature conservation can do anything special." Although some proposals for active consideration of the phenomena were voiced, most were limited to general suggestions such as "avoid or counteract [them] professionally" or "use the best and most far-sighted communication concepts and public outreach possible." This general uncertainty and lack of action demonstrate that it is necessary to explore strategies for dealing with echo chambers and filter bubbles.

So far, only a few suggestions for action can be found in scientific literature. For example, Fraser and Fraser (2017) suggest countering the effects of both digital and analogue echo chambers by using methods with high visibility that are accessible to everyone, such as an eye-catching art installation in a public space. This could increase public awareness and participation in a conservation issue (Fraser and Fraser 2017). Furthermore, Walter et al. (2018) advise climate scientists to make evidence-based knowledge accessible to the general public. To achieve this goal, nature conservation actors could go beyond the liberal elite media and engage with tabloid and conservative media to better inform a wider range of social groups in their echo chambers and filter bubbles (Walter et al. 2018). A target-oriented and strategic communication was also endorsed by several of the survey respondents, for example through "trust promotion with "colorful messages"" and using "more digital media to document successful measures, e.g., in species protection." In contrast, other answers suggested avoiding filter bubbles altogether by using "exclusively open source solutions" or by setting up a transparent "platform for the exchange of positions" to counteract echo chambers. However, as one of the respondents pointed out, distancing oneself from mainstream communication channels like this may lead to an increased isolation of nature conservation actors and their subsequent inability to reach other societal groups. In summary, the few, sometimes contradictory and unverified concrete recommendations for action from the experts and literature show a need for research into the validity of these suggestions and if possible, their refinement. In a further step, action should be taken to implement the developed strategies in nature conservation practice.

In this context, potential opportunities offered by echo chambers and filter bubbles should not be neglected. Although one survey respondent reported that "pro-nature conservation messages are moved up in Google's ranking, thus emphasizing their importance," the overwhelming majority of positive effects addressed by the experts concerned increased motivation and commitment of conservationists, as we explained in detail in our response to the second research question. Moreover, Hermwille and Siemons (2018) addressed another positive side of echo chambers, namely their potential strategic modification to encourage pro-conservation politics. It would therefore be recommendable to conduct further research concerning the active harnessing of potential positive effects of echo chambers and filter bubbles, even though they are already, arguably unconsciously, used to promote motivation and commitment.

At the same time, as several survey respondents and Titeca and Edmond (2019) noted, attention should be paid to ensure that the utilization of echo chamber and filter bubble effects does not lead to radicalization or ineffective nature conservation work. Madzwamuse et al. (2020), for example, describe how Western organizations create echo chambers to justify each other's campaigns in African wildlife conservation. The fact that these are often less effective because local stakeholders are not involved is not considered by those organizations (Madzwamuse et al. 2020). Similarly, Pilkington (2016) criticizes that some scientists use the echo chamber of public discourse to masquerade value judgements as facts in order to spread opinions to promote their own interests. One of the experts expressed the following opinion on this subject: "Sustainable nature conservation only works through long-term commitment and a constant reassessment of the facts. Echo chambers and filter bubbles work in the short term and lead to a hardening of positions, as a result of which nature conservation can only lose in the long term."

\section{DISCUSSION}

\section{Methodological limitations}

For some of the search strings used in the literature review, the number of literature sources suggested by Google Scholar was in the five-digit range, which made a complete review of all literature impossible. After Google Scholar successively suggested 30 literature sources that proved to be irrelevant for the literature review, the search was stopped. Therefore, it cannot be ruled out that relevant sources remained unnoticed, which could be improved in future studies by a more extensive literature search. Furthermore, the definition of nature conservation used in this study is based on the Federal Nature Conservation Act of Germany and does not necessarily reflect the international understanding of the term. Because of this, some studies based on a different definition of nature conservation may have remained undiscovered during the literature review. Additionally, the definition used here leads to overlaps with the areas of climate and environmental protection. Because it is difficult to separate the fields in these overlapping areas, sources that could also be allocated to climate protection and environmental conservation were also included in the literature review.

Because all the respondents work in German nature conservation, the survey results are not necessarily internationally representative. Further research could hence embrace an international scope to complement the findings presented here. To gather data from a wider range of nature conservation actors than the experts contacted for the survey, future studies could also consider conducting less targeted surveys in terms of content and target group. Additionally, the expert survey was based on the aim of this study to provide solely an initial explorative insight into the relevance of echo chambers and filter bubbles for nature conservation. In the future, the collection and analysis of statistically representative data could complement the insights presented here. More elaborate qualitative methods such as faceto-face surveys are also recommended to collect more in-depth 
information and to allow for follow-up questions. Respective interview questions could be based on the findings of this study.

\section{Discord concerning echo chambers and filter bubbles in the scientific community}

This study has revealed a growing concern regarding the potential impact of echo chambers and filter bubbles on nature conservation. However, the overall scientific community is divided when it comes to the question of the actual existence and practical relevance of the two phenomena. Some studies completely question the relevance of the phenomena or attribute them with only minor influence on public opinion and processes of polarization (e.g., Barberá et al. 2015, Flaxman et al. 2016, Zuiderveen Borgesius et al. 2016). At the same time, several publications have provided ample proof for the formation and effects of digital echo chambers and filter bubbles (e.g., Gaines and Mondak 2009, Nguyen et al. 2014, Vaccari et al. 2016, Chitra and Musco 2019, Geschke et al. 2019). Despite the lack of consensus in the scientific community, these studies are a strong indicator that echo chambers and filter bubbles are probably more than abstract concepts conceived in the face of a constantly evolving digital environment. This makes the phenomena and their potential impact on nature conservation worthy of further investigation.

Some of the aspects that may have contributed to the disagreement about echo chambers and filter bubbles in the scientific community should be considered in future research endeavors. First, following a holistic approach, the formation of opinions and public polarization in social networks should be regarded in the context of individual user characteristics and offline environment (Nguyen et al. 2014, Barberá et al. 2015, Vaccari et al. 2016). Second, empirical studies should avoid generalized statements that transcend their subject-matter. This is due to the highly heterogeneous factors that can influence study results concerning echo chambers and filter bubbles, such as a fluctuating societal context, different functionalities of social networks, as well as nontransparent and ever-evolving filter algorithms (Nguyen et al. 2014, Zuiderveen Borgesius et al. 2016). Last, as this study has shown, the understanding of echo chambers and filter bubbles is inconsistent both in literature and conservation practice. Therefore, in future research, it is essential to ensure that the terms are correctly defined and used to avoid any disagreement based on a semantic misunderstanding.

\section{Reasons for the special consideration of digital echo chambers and filter bubbles}

One fact that has long been accepted by the scientific community is the existence of offline echo chambers (Chitra and Musco 2019). Three main aspects distinguish digital echo chambers from their analogue counterparts and make them and the recently emerged phenomenon of filter bubbles particularly noteworthy in conservation research.

First, digital echo chambers and filter bubbles can reinforce analogue echo chambers (Müller et al. 2020). To avoid this, nature conservation should research and manage digital echo chambers, filter bubbles, and their effects on offline echo chambers. This can also help nature conservation to improve its communication with the public and break out of existing analogue echo chambers. This would be especially useful for conservation disciplines strongly reliant on public participation processes, such as landscape planning or environmental education. Overall, the comprehension and active consideration of these novel communication phenomena is crucial for the societal acceptance upon which nature conservation depends (cf. Brendle 2002, Schuster 2008, Licht1 2009).

Second, various societal powers advance their interests using social media, frequently in morally questionable ways. This stands in stark contrast with the supposed merit of new digital communication channels for the democratic public (cf. Lange and Santarius 2018). Examples of this sort of behavior include manipulation of Twitter discourse by regimes in the ongoing military Persian Gulf Crisis (Leber and Abrahams 2019) and mass fabrication of social media posts by the Chinese government to distract the public from criticizing the regime (King et al. 2017). These propagandic utilizations of social media for political purposes can have devastating effects on human rights and the foundations of democracy (cf. King et al. 2017, Leber and Abrahams 2019). Such misuse of new media can also concern nature conservation topics as our study results demonstrate most prominently in the rise of mis- and disinformation about climate protection amongst policy makers and the public (cf. Paulo 2018, Colston and Thomas 2019, Jasny and Fisher 2019). Furthermore, these intentional polarization processes are far reaching and highly efficacious because of the globalized, immediate, and easyto-use nature of social networks and can be reinforced by digital echo chambers and filter bubbles (Geschke et al. 2019, Müller et al. 2020). Such utilization of social media and the two phenomena should therefore be actively taken into account by nature conservation.

Third, digital echo chambers and filter bubbles are particularly prone to enhancing other problematic digital phenomena such as populism, polarization, as well as mis- and disinformation (Chitra and Musco 2019, Müller et al. 2020, Shu et al. 2020). These processes have a negative impact on the representation of environmental interests on the Internet and promote environmental skepticism (Cox 2010, Frohn and Rosebrock 2018). As a result, the seriousness of environmental issues is disputed and the credibility of conservation science is questioned (Cox 2010). Overall, digital echo chambers and filter bubbles make the handling of nature conservation issues in a post-truth world particularly difficult and should thus be specially considered (cf. Shu et al. 2020).

\section{Limited awareness of echo chambers and filter bubbles in the field of nature conservation}

The occurrence and effects of digital echo chambers and filter bubbles in the context of nature conservation seem to have aroused little interest in nature conservation literature and practice so far. The sparse discussion of the two phenomena in this field seems to indicate a limited awareness of the topic.

One indicator for this observation is the fact that nature conservation research of the two phenomena has only emerged in recent years, as the literature review showed. Furthermore, only 2 of 40 identified sources focused on possible effects of echo chambers on nature conservation as the main topic of the source (category A sources). Additionally, all of the experts knew at least one of the phenomena. This fact could indicate a nonresponse bias, which would mean that only people with preexisting knowledge or views on the phenomena responded to the survey 
(Marsden and Wright 2010). In this case, the response rate of around $6 \%$ would demonstrate a lack of sensibilization or interest for the topic in nature conservation (Marsden and Wright 2010).

A possible reason for the low level of attention given to the topic in conservation literature and practice could be the relatively recent emergence of the two phenomena and increasing digitalization (Pariser 2011, Barberá et al. 2015). However, the abundance of literature on echo chambers and filter bubbles in other scientific sectors such as political science, economic science, or sociology contradict this hypothesis (e.g., Flaxman et al. 2016, Dubois and Blank 2018, Sindermann et al. 2020). In general, nature conservation appears to be making slow progress in dealing with new aspects of the ongoing digitalization. Even in 2005, 12 years after the commercial introduction of the Internet, there was a lack of research on online communication in the conservation field (Peters et al. 2005). Perhaps this slow approach to digital issues contributed to the limited but increasing awareness of echo chambers and filter bubbles in nature conservation practice and literature.

\section{Strong focus on climate protection in scientific literature}

The literature review shows that echo chambers and filter bubbles have so far been scientifically investigated mainly in connection with climate protection. The reason for this focus in the identified literature cannot be determined with certainty. Out of the eleven search terms used in the literature review, only one was chosen that specifically addresses the topic of climate protection. The search term "climate protection" was chosen because the German Federal Nature Conservation Act (2009) states in $\S 1$ that air and climate must also be protected by nature conservation and landscape management measures. As addressed in the methodological discussion, this legally based thematic overlap between nature conservation and climate protection is the reason for the inclusion of sources focused on climate protection in the literature review.

The focus on climate protection can probably be explained by the increasing importance of the topic. In this context, the attention of the mass media and politicians to climate change and climate protection issues has increased significantly in the last three decades (Weingart et al. 2008, Schmidt et al. 2013, Hoffman 2015). It has also become clear that social media discussions on climate change often take place in polarizing debates with climate change "sceptics" on the one hand and "activists" on the other (Williams et al. 2015). In this context, like-minded people support each other, opposing fronts are hardened, and the formation of echo chambers is favored (Williams et al. 2015). All in all, the global prominence and polarizing nature of climate issues could thus explain the focus on them in the identified conservation literature on echo chambers and filter bubbles.

\section{Active consideration of echo chambers and filter bubbles in nature conservation practice}

As the expert survey has shown, the consideration of echo chambers and filter bubbles in nature conservation practice is lacking and for the most part does not extend beyond a basic awareness. Although this basic awareness may at least enable nature conservation actors to rudimentarily take into account the effects of echo chambers and filter bubbles on their work, specific handling strategies are necessary to achieve a greater effect. In this context, the surveyed experts and identified studies made a few broad suggestions for action, including the avoidance, reduction, and utilization of echo chambers and filter bubbles. Although these may prove valuable for nature conservation, they should only be implemented with caution to prevent any unforeseen and undesirable side effects.

Concerning the potential utilization of echo chambers and filter bubbles by nature conservation to sway public opinion, several studies and respondents warned of a potential loss of nature conservation effectiveness (cf. Titeca and Edmond 2019, Madzwamuse et al. 2020). In addition to this risk and the moral questionability of such practices, it is also doubtful whether the views of nature conservation adversaries or uninterested people could be affected by such an approach. This is due to the fact that echo chambers and filter bubbles merely reinforce already existing interests and views by amplifying the confirmation bias of people (Geschke et al. 2019, Müller et al. 2020). The two phenomena are therefore unsuitable for engaging people who do not already hold a positive view of nature conservation. Furthermore, previous research has shown that communication in social media-where echo chambers and filter bubbles are most prominent-is not suited for short-term sway of public opinion (cf. Harris and Harrigan 2015). Instead, long-term communication strategies are required to effectively communicate with the public (Harris and Harrigan 2015). This was also pointed out by several of the surveyed nature conservation experts.

An additional proposal for action is the publication of nature conservation science in tabloid and conservatively oriented media to avoid communicational obstacles caused by echo chambers and filter bubbles (Walter et al. 2018). However, if such outlets were willing to publish nature conservation content, it may prove difficult to write articles that are well received by the respective target groups without risking a loss of scientific accuracy or focusing heavily on negative news (Boykoff 2008). The same caution should be applied when trying to reach people in their echo chambers and filter bubbles by communicating in social networks like Twitter (cf. Brossard 2013, Bombaci et al. 2016).

Another approach suggested by the interviewed experts is target group-oriented communication to bypass echo chambers and filter bubbles. To effectively address the public, nature conservation practitioners must not only adapt the conveyed contents to the audience but also their choice of media and communication style (cf. Schuster 2008). This can be quite difficult however, because the respective needs and preferences of the public are diverse and complex. For this reason, target-group oriented communication utilizes various models that cluster citizens into groups (Scholl and Hage 2004). This strategy has previously been discussed and employed in nature conservation (e.g., Scholl and Hage 2004, Schuster 2008) as well as other societal sectors, particularly in marketing (e.g., Sathish and Rajamohan 2012, Piatykop and Pronina 2020). However, although such sociological models may be profitable in a commercial context, their cost-benefit-ratio is a point of concern for non-profit conservation actors (Scholl and Hage 2004). Furthermore, just like in the marketing sector (Crane and Desmond 2002), nature conservation must carefully consider to what extent tailoring communication methods and contents to a target group may constitute manipulation. Last, such strategies 
could potentially reinforce existing echo chambers and filter bubbles by adapting to the views and interests of the audience.

In addition to further researching and testing the existing strategies for dealing with the phenomena in nature conservation practice, a review of methods stemming from other fields of research could provide valuable insights. Potentially relevant strategies could be adjusting educational curricula to prevent echo chambers (cf. Passe et al. 2018), advocating transparency of algorithms that generate filter bubbles (cf. Nguyen et al. 2014), using urban interfaces such as pervasive displays to expose citizens to informational diversity (cf. Foth et al. 2016), or promoting software solutions to escape filter bubbles (cf. Bozdag and van den Hoven 2015). Furthermore, nature conservationists can refer to literature on digital mis- and disinformation to reduce their own susceptibility to echo chambers and filter bubbles. In this context, they could cultivate fact checking practices (cf. Dubois et al. 2020), use computational resources to detect disinformation (cf. Shu et al. 2020), or learn about neurological factors in rectifying incorrect beliefs (cf. Seifert 2002). In any case, research into the strategies employed in other fields is highly recommended because most nature conservation issues are deeply intertwined with other societal factors. An awareness of how echo chambers and filter bubbles are studied, handled, and used in other fields like politics (e.g., Bozdag and van den Hoven 2015, Jasny and Fisher 2019) can enable nature conservation to communicate and function more effectively in its overall societal context.

\section{CONCLUSION}

The results of this study indicate that echo chambers and filter bubbles are being addressed in nature conservation literature and practice to a small but increasing extent. Furthermore, it is recognized that they pose more risks than potential advantages for nature conservation communication. On the one hand, nature conservation actors can use echo chambers to increase each other's motivation and commitment to the cause. On the other hand, echo chambers and filter bubbles may lead to communication issues and hinder the exchange between nature conservation actors and other societal groups. However, the understanding of the exact processes associated with echo chambers and filter bubbles is insufficient and should be subject to further investigation. The study also identified a significant need for action and research concerning the strategic consideration and handling of echo chambers and filter bubbles in nature conservation practice. Existing research from other scientific fields could be of use for this purpose.

Nature conservation issues are intertwined with many parts of modern society. Issues of global importance such as climate change are part of political, public, and scientific discourse. At the same time, regional issues such as the reintroduction of wolves near human-populated areas are being discussed by a wide range of actors. Regardless of scale, topic, or involved parties, echo chambers and filter bubbles can influence the communication of nature conservation topics. To make a responsible and effective contribution to the well-being of nature and society, nature conservation must keep abreast of new communication factors that arise in the age of digitalization.
Responses to this article can be read online at: https://www.ecologyandsociety.org/issues/responses. php/12549

\section{Acknowledgments:}

We would like to thank Prof. Dr. Stefan Heiland for his continuous support, encouragement, and open feedback. We also acknowledge support by the German Research Foundation and the Open Access Publication Fund of TU Berlin. Furthermore, we would like to thank our two anonymous reviewers for their helpful and constructive feedback. Last, we want to express our appreciation for the advice our friends and colleagues provided as well as for the nature conservation experts that completed our survey.

\section{Data Availability:}

All data used during the study are available in the uploaded appendices.

\section{LITERATURE CITED}

Adamic, L. A., and N. Glance. 2005. The political blogosphere and the 2004 U.S. election: divided they blog. Proceedings of the 3rd international workshop on Link discovery, August, 2005, Chicago, USA. Association for Computing Machinery, New York, New York, USA. https://doi.org/10.1145/1134271.1134277

Adomßent, M. 2005. Naturschutzkommunikation. Pages 428-438 in G. Michelsen, and J. Godemann, editors. Handbuch Nachhaltigkeitskommunikation. Grundlagen und Praxis. Oekom-Verlag, Munich, Germany.

Ascher, D., and W. Ascher. 2016. Inducing better stakeholder searches for environmental information relevant to coastal conservation. Pages 153-174 in B. H. MacDonald, S. S. Soomai, E. M. De Santo, and P. G. Wells, editors. Science, information, and policy interface for effective coastal and ocean management. CRC Press, Boca Raton, Florida, USA. [online] URL: https:// library.oapen.org/bitstream/handle/20.500.12657/22973/9781498731706 text.pdf?sequence $=1$

Barberá, P., J. Jost, J. Nagler, J. Tucker, and R. Bonneau. 2015. Tweeting from left to right: is online political communication more than an echo chamber? Psychological Science 26 (10):1531-1542. https://doi.org/10.1177/0956797615594620

Bell, T. 2017. Optimisation of fuel reduction burning regimes for fuel reduction, carbon, water and vegetation outcomes: annual project report 2016-2017. Bushfire and Natural Hazards CRC, Melbourne, Australia. [online] URL: https://www.bnhcrc.com. $\mathrm{au} / \mathrm{sites} / \mathrm{default} / \mathrm{files} / \mathrm{managed} / \mathrm{downloads/na10}$ bell with eu annual_report_2016-2017_-_mpr_approved.pdf

Bombaci, S. P., C. M. Farr, H. T. Gallo, A. M. Mangan, L. T. Stinson, M. Kaushik, and L. Pejchar. 2016. Using Twitter to communicate conservation science from a professional conference. Conservation Biology 30(1):216-225. https://doi. org/10.1111/cobi.12570 
Bowden, C., and S. Galindo-Gonzalez. 2015. Interviewing when you're not face-to-face: the use of email interviews in a phenomenological study. International Journal of Doctoral Studies 10:79-92. https://doi.org/10.28945/2104

Boykoff, M. T. 2008. The cultural politics of climate change discourse in UK tabloids. Political Geography 27(5):549-569. https://doi.org/10.1016/j.polgeo.2008.05.002

Bozdag, E., and J. van den Hoven. 2015. Breaking the filter bubble: democracy and design. Ethics and Information Technology 17:249-265. https://doi.org/10.1007/s10676-015-9380y

Braun, V., and V. Clarke. 2012. Thematic analysis. Pages 57-71 in H. Cooper, P. M. Camic, D. L. Long, A. T. Panter, D. Rindskopf, and K. J. Sher, editors. APA handbooks in psychology. APA handbook of research methods in psychology, Vol. 2. Research designs: quantitative, qualitative, neuropsychological, and biological. American Psychological Association, Washington, D. C., USA. https://doi.org/10.1037/13620-004

Brendle, U. 2002. Kommunikation und Naturschutz. Überlegungen zur Akzeptanzsteigerung des Naturschutzes. Pages 115-133 in K.-H. Erdmann and C. Schell, editors. Natur zwischen Wandel und Veränderung: Ursache, Wirkungen, Konsequenzen. Springer, Berlin, Germany. https://doi. org/10.1007/978-3-642-56356-0_9

Briner, R., and D. Denyer. 2012. Systematic review and evidence synthesis as a practice and scholarship tool. Pages 112-129 in D. M. Rousseau, editor. The Oxford handbook of evidence-based management. Oxford University Press, New York, New York, USA. https://doi.org/10.1093/oxfordhb/9780199763986.013.0007

Brossard, D. 2013. New media landscapes and the science information consumer. Proceedings of the National Academy of Sciences of the United States of America 110(3):14096-14101. https://doi.org/10.1073/pnas.1212744110

Burbach, L., P. Halbach, M. Ziefle, and A. Calero Valdez. 2019. Bubble trouble: strategies against filter bubbles in online social networks. Pages 441-456 in V. Duffy, editor. Digital human modeling and applications in health, safety, ergonomics and risk management. Healthcare Applications. HCII 2019. Lecture Notes in Computer Science, volume 11582. Springer, Cham, Switzerland. https://doi.org/10.1007/978-3-030-22219-2 33

Büscher, B. 2016. Nature 2.0: exploring and theorizing the links between new media and nature conservation. New Media \& Society 18(5):726-743. https://doi.org/10.1177/1461444814545841

Chitra, U., and C. Musco. 2019. Understanding filter bubbles and polarization in social networks. Workshop on Issues of Sentiment Discovery and Opinion Mining 2019, 4 August 2019, Anchorage, Alaska, USA. [online] URL: https://sentic.net/wisdom2019chitra. pdf

Clermont, H. 2018. The underbelly of economy versus environment conflicts: detangling sources of tension in contentious natural resource decision. Dissertation. Royal Roads University, Victoria, British Columbia, Canada. http://dx.doi. org/10.25316/IR-351
Colston, N., and J. Thomas. 2019. Climate change skeptics teach climate literacy? A critical discourse analysis of children's books. Journal of Science Communication 18(4):A02. https://doi. org/10.22323/2.18040202

Cota, W., S. C. Ferreira, R. Pastor-Satorras, and M. Starnini. 2019. Quantifying echo chamber effects in information spreading over political communication networks. European Physical Journal Data Science 8:35. https://doi.org/10.1140/epjds/ s13688-019-0213-9

Côté, I. M., and E. S. Darling. 2018. Scientists on Twitter: preaching to the choir or singing from the rooftops? FACETS 3 (1):682-694. https://doi.org/10.1139/facets-2018-0002

Cox, R. 2010. Environmental communication and the public sphere. Second edition. SAGE, Thousand Oaks, California, USA.

Crane, A., and J. Desmond. 2002. Societal marketing and morality. European Journal of Marketing 36(5/6):548-569. https://doi.org/10.1108/03090560210423014

Denyer, D., and D. Tranfield. 2009. Producing a systematic review. Pages 671-689 in D. A. Buchanan and A. Bryman, editors. The Sage handbook of organizational research methods. SAGE, London, UK.

Dubois, E., and G. Blank. 2018. The echo chamber is overstated: the moderating effect of political interest and diverse media. Information, Communication \& Society 21(5):729-745. https:// doi.org/10.1080/1369118X.2018.1428656

Dubois, E., S. Minaeian, A. Paquet-Labelle, and S. Beaudry. 2020. Who to trust on social media: how opinion leaders and seekers avoid disinformation and echo chambers. Social Media + Society 6(2). https://doi.org/10.1177/2056305120913993

Elshof, L. 2015. Challenging climate 'inactivism' and creating critical citziens. Pages 165-186 in D. Selby, and F. Kagawa, editors. Sustainability frontiers: critical and transformative voices from the borderlands of sustainability education. Barbara Budrich, Opladen, Germany.

Eser, U. 2016. Naturschutz, Kommunikation und Ethik: Brücken bauen zwischen Theorie und Praxis: Eine Einführung in die ethischen Grundlagen der Naturschutzkommunikation mit Impulsen für die Praxis. In Bundesamt für Naturschutz, editor. BfN-Skripten 443. Druckerei des Bundesministeriums für Umwelt, Naturschutz, Bau und Reaktorsicherheit, Bonn, Germany.

Farrell, J. 2015. Politics: echo chambers and false certainty. Nature Climate Change 5(8):719-720. https://doi.org/10.1038/nclimate2732

Flaxman, S., S. Goel, and J. Rao. 2016. Filter bubbles, echo chambers, and online news consumption. Public Opinion Quarterly 80(S1):298-320. https://doi.org/10.1093/poq/nfw006

Foth, M., M. Tomitsch, L. Forlano, M. Haeusler, and C. Satchell. 2016. Citizens breaking out of filter bubbles: urban screens as civic media. Proceedings of the 5th ACM International Symposium on Pervasive Displays, June, 2016, Oulu, Finland. Association for Computing Machinery, New York, New York, USA. https://doi.org/10.1145/2914920.2915010 
Fraser, H., and R. Fraser. 2017. What rises above the white noise: the possibility of hearing truth in a post-truth world. Goose 16 (1):28. [online] URL: https://scholars.wlu.ca/thegoose/vol16/ iss $1 / 28$

Frohn, H.-W., and J. Rosebrock, editors. 2018. Herausforderungen für die Umweltkommunikation - Der Deutsche Naturschutzring, die Naturschutzverwaltungen und der Wandel der Protestkultur. Oekom-Verlag, München, Germany.

Gaines, B. J., and J. J. Mondak. 2009. Typing together? Clustering of ideological types in online social networks. Journal of Information Technology \& Politics 6(3-4):216-231. https://doi. org/10.1080/19331680903031531

Geschke, D., J. Lorenz, and P. Holtz. 2019. The triple-filter bubble: using agent-based modelling to test a meta-theoretical framework for the emergence of filter bubbles and echo chambers. British Journal of Social Psychology 58(1):129-149. https://doi. org/10.1111/bjso. 12286

Harris, L., and P. Harrigan. 2015. Social media in politics: the ultimate voter engagement tool or simply an echo chamber? Journal of Political Marketing 14(3):251-283. https://doi. org/10.1080/15377857.2012.693059

Hartl, P., and D. Ramsauer. 2017. Bundestagswahl 2017: Einblicke in das Tweetverhalten von Politikern mit Netzwerkanalyse und topic modelling. Universität Regensburg, Regensburg, Germany. [online] URL: https://dramsauer.me/pdf/ btw.pdf

Heiland, S. 1999. Voraussetzungen Erfolgreichen Naturschutzes: Individuelle und gesellschaftliche Bedingungen umweltgerechten Verhaltens, ihre Bedeutung für den Naturschutz und die Durchsetzbarkeit seiner Ziele. Schriftenreihe Angewandter Umweltschutz. Ecomed-Verlag, Landsberg, Germany.

Hermwille, L., and A. Siemons. 2018. What makes an ideal global stocktake? A functional analysis. Umweltbundesamt, DessauRoßlau, Germany. [online] URL: https://epub.wupperinst.org/ frontdoor/deliver/index/docId/7141/file/7141 Hermwille.pdf

Hindmarsh, R., and D. L. Calibeo. 2017. The Potential of New and Social Media for Environmental Activism. Pages 55-70 in S. Crabu, P. Giardullo, F. Miele, and M. Turrini, editors. Sociotechnical environments. Proceedings of the 6th STS Italia Conference. STS Italia Publishing, Milano, Italy.

Hoffman, A. 2015. How culture shapes the climate change debate. Stanford University Press, Stanford, California, USA. https://doi. org/10.1515/9780804795050

Hölderle, J. 2016. Expertise social media. Technische Universität Berlin, Berlin, Germany. [online] URL: https://www.landschaft. tu-berlin.de/fileadmin/fg218/Forschung/Expertise-Social-Media. pdf

Jasny, L., and D. Fisher. 2019. Echo chambers in climate science. Environmental Research Communications 1(10):101003. https:// doi.org/10.1088/2515-7620/ab491c

King, G., J. Pan, and M. Roberts. 2017. How the Chinese government fabricates social media posts for strategic distraction, not engaged argument. American Political Science Review 111 (3):484-501. https://doi.org/10.1017/S0003055417000144
Lange, S., and T. Santarius. 2018. Smarte grüne Welt? Digitalisierung zwischen Überwachung, Konsum und Nachhaltigkeit. Oekom-Verlag, Munich, Germany.

Leber, A., and A. Abrahams. 2019. A storm of tweets: social media manipulation during the Gulf Crisis. Review of Middle East Studies 53(2):241-258. https://doi.org/10.1017/rms.2019.45

Lichtl, M., editor. 2009. Leitmotive für eine moderne Kommunikation zur biologischen Vielfalt: Ergebnisse des F+EVorhabens "Natur und Biodiversität in der politischen Kommunikation". Bundesamt für Naturschutz, Bonn-Bad Godesberg, Germany.

Madzwamuse, M., E. Rihoy, and M. Louis. 2020. Contested conservation: implications for rights, democratization, and citizenship in Southern Africa. Development 63:67-73. https:// doi.org/10.1057/s41301-020-00237-1

Marsden, P., and J. Wright, editors. 2010. Handbook of survey research. Second edition. Emerald, Bingley, UK.

Metson, T. 2018. Rampant development in a park of the people: save Pirin and lessons in the resistance against neoliberalism. Thesis. Lund University, Lund, Sweden. [online] URL: http://lup.

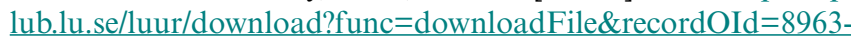
$\underline{828 \& \text { fileOId }=8963829}$

Müller, J., V. Hösel, and A. Tellier. 2020. Filter bubbles, echo chambers, and reinforcement: tracing populism in election data. arXiv:2007.03910. [online] URL: https://arxiv.org/pdf/2007.03910. pdf

Nguyen, T. T., P.-M. Hui, F. M. Harper, L. Terveen, and J. A. Konstan. 2014. Exploring the filter bubble: the effect of using recommender systems on content diversity. Proceedings of the 23rd International Conference on World Wide Web, April 7-11, 2014, Seoul, South Korea. Association for Computing Machinery, New York, New York, USA. https://doi. org/10.1145/2566486.2568012

Pariser, E. 2011. The filter bubble: what the internet is hiding from you. First edition. Viking, Penguin Books, London, UK.

Passe, J., C. Drake, and L. Mayger. 2018. Homophily, echo chambers, \& selective exposure in social networks: what should civic educators do? Journal of Social Studies Research 42 (3):261-271. https://doi.org/10.1016/j.jssr.2017.08.001

Paulo, N. 2018. Die Rationalität postfaktischen Denkens. Behemoth: A Journal on Civilisation 11(2):55-73. [online] URL: https://doi.org/10.6094/behemoth.2018.11.2.988

Peters, U., S. Rümmele, and M. Große Ophoff, editors. 2005. Erfolgreiche Umweltkommunikation im Internet: Studie: Internetanwendungen im Natur-und Umweltschutz. Erich Schmidt Verlag, Berlin, Germany.

Piatykop, O., and O. Pronina. 2020. Model selection of the target audience in social networks in order to promote the product. CEUR WS 2604(29):396-406. [online] URL: http://ceur-ws.org/ Vol-2604/paper29.pdf

Pilkington, C. 2016. Deconstructing the modern research paper: a case study. Undergraduate Honours Degree, Dalhousie University, Halifax, Nova Scotia, Canada. [online] URL: https:// 
static1.squarespace.com/static/5b3babac70e802454aede 034/ t/5b5f419d0e2e726a186be180/1532969377057/Pilkington_UGThesis 160424.pdf

Sathish, S., and A. Rajamohan. 2012. Consumer behaviour and lifestyle marketing. International Journal of Marketing, Financial Services \& Management Research 1(10):152-166. [online] URL: http://indianresearchjournals.com/pdf/IJMFSMR/2012/ October/13.pdf

Schmidt, A., A. Ivanova, and M. S. Schäfer. 2013. Media attention for climate change around the world: a comparative analysis of newspaper coverage in 27 countries. Global Environmental Change 23(5):1233-1248. https://doi.org/10.1016/j.gloenvcha.2013.07.020

Scholl, G., and M. Hage. 2004. Lebensstile, Lebensführung und Nachhaltigkeit. Schriftreihe des IÖW 176/04. Institut für Ökologische Wirtschaftsforschung, Berlin, Germany. [online] URL: https://www.ioew.de/uploads/tx_ukioewdb/ IOEW SR 176 Lebensstile Lebensfuehrung und Nachhaltigkeit. pdf

Schuster, K. 2008. Gesellschaft und Naturschutz: Empirische Grundlagen für eine lebensstilorientierte Naturschutzkommunikation. First edition. Landwirtschaftsverlag Münster, Bonn-Bad Godesberg, Germany.

Seifert, C. 2002. The continued influence of misinformation in memory: What makes a correction effective? Psychology of Learning and Motivation 41:265-292. https://doi.org/10.1016/ $\underline{\text { S0079-7421(02)80009-3 }}$

Shu, K., A. Bhattacharjee, F. Alatawi, T. H. Nazer, K. Ding, M. Karami, and H. Liu. 2020. Combating disinformation in a social media age. WIRES Data Mining and Knowledge Discovery 10 (6):e1385. https://doi.org/10.1002/widm.1385

Sindermann, C., J. Elhai, M. Moshagen, and C. Montag. 2020. Age, gender, personality, ideological attitudes and individual differences in a person's news spectrum: how many and who might be prone to "filter bubbles" and "echo chambers" online? Heliyon 6(1):e03214. https://doi.org/10.1016/j.heliyon.2020.e03214

Stark, B., M. Magin, and P. Jürgens. 2021. Maßlos überschätzt. Ein Überblick über theoretische Annahmen und empirische Befunde zu Filterblasen und Echokammern. Pages 303-321 in M. Eisenegger, M. Prinzing, P. Ettinger, and R. Blum, editors. Digitaler Strukturwandel der Öffentlichkeit: Historische Verortung, Modelle und Konsequenzen. Springer VS, Wiesbaden, Germany. https://doi.org/10.1007/978-3-658-32133-8 17

Sunstein, C. R. 2001. republic.com. Princeton University Press, Princeton, New Jersey, USA.

Tandoc, E. C., D. Lim, and R. Ling. 2020. Diffusion of disinformation: how social media users respond to fake news and why. Journalism 21(3):381-398. https://doi.org/10.1177/1464884919868325

Terren, L., and R. Borge-Bravo. 2021. Echo chambers on social media: a systematic review of the literature. Review of Communication Research 9:99-118. https://doi.org/10.12840/ ISSN.2255-4165.028
Theile, S. 2018. Social Media: Chancen und Herausforderungen für die räumliche Planung und Mitwirkung. Dissertation. Universität Kassel, Kassel, Germany. [online] URL: https://d-nb. info/1174922133/34

Titeca, K., and P. Edmond. 2019. Outside the frame: looking beyond the myth of Garamba's LRA ivory-terrorism nexus. Conservation and Society 17(3):258-269. [online] URL: https:// www.jstor.org/stable/26677962

Vaccari, C., A. Valeriani, P. Barberá, J. T. Jost, J. Nagler, and J. A. Tucker. 2016. Of echo chambers and contrarian clubs: exposure to political disagreement among German and Italian users of Twitter. Social Media + Society 2(3). [online] URL: https://doi.org/10.1177/2056305116664221

Walter, S., M. Brüggemann, and S. Engesser. 2018. Echo chambers of denial: explaining user comments on climate change. Environmental Communication 12(2):204-217. https://doi. org/10.1080/17524032.2017.1394893

Waters, K. M. 2019. The influence of social media interactions on perceptions of and attitudes toward Mexican gray wolves. Thesis. The University of Arizona, Tucson, Arizona, USA. [online] URL: https://repository.arizona.edu/bitstream/ handle/10150/634268/azu_etd_17332_sip1_m.pdf? sequence $=1 \&$ is 1 llowed $=\mathrm{y}$

Weingart, P., A. Engels, and P. Pansegrau. 2008. Von der Hypothese zur Katastrophe: Der anthropogene Klimawandel im Diskurs zwischen Wissenschaft, Politik und Massenmedien. Second edition. Verlag Barbara Budrich, Opladen, Germany. https://doi.org/10.2307/j.ctvdf064x

Williams, H. T. P., J. R. McMurray, T. Kurz, and F. H. Lambert. 2015. Network analysis reveals open forums and echo chambers in social media discussions of climate change. Global Environmental Change 32:126-138. https://doi.org/10.1016/j. gloenvcha.2015.03.006

Zegers, L. 2018. Stuck in denial versus moving with science: climate change discourses and the influence of the denial machine on left and right news media. Thesis. Leiden University, Leiden, Netherlands. [online] URL: https://openaccess.leidenuniv.nl/ bitstream/handle/1887/57935/20180118\%20MA \%20thesis $\% 20$ Luuk $\%_{0}$ 20Zegers $\% 20$ Final $\% 20$ Version.pdf?sequence $=1$

Zuiderveen Borgesius, F. J., D. Trilling, J. Möller, B. Bodó, C. H. de Vreese, and N. Helberger. 2016. Should we worry about filter bubbles? Internet policy review. Journal on Internet Regulation 5 (1). https://doi.org/10.14763/2016.1.401 
Appendix 1 Literature review search strings

The search strings combine keywords from the field of nature conservation and the terms echo chamber or filter bubble. The selection of nature conservation terms was based on the Federal Nature Conservation Act of Germany. To ensure that both terms were used in the sources suggested by the search engine the individual search strings were constructed by linking the terms echo chamber or filter bubble with a term from the field of nature conservation using the Boolean operator "AND". If a term consisted of several words, they were enclosed in quotation marks to ensure their treatment as a unit in the search process.

\begin{tabular}{|c|c|c|c|}
\hline \multicolumn{2}{|c|}{ Echo chamber and filter bubble } & \multicolumn{2}{|c|}{ Nature conservation } \\
\hline English & German & English & German \\
\hline filter bubble & Filterblase & nature conservation & Naturschutz \\
\hline echo chamber & Echokammer & environment & Umwelt \\
\hline & & $\begin{array}{l}\text { conservation area, } \\
\text { protected area }\end{array}$ & Schutzgebiet \\
\hline & & landscape planning & Landschaftsplanung \\
\hline & & $\begin{array}{c}\text { nature conservation area, } \\
\text { nature reserve }\end{array}$ & Naturschutzgebiet \\
\hline & & ecosystem & Ökosystem \\
\hline & & climate protection & Klimaschutz \\
\hline & & $\begin{array}{c}\text { biodiversity, biological } \\
\text { diversity }\end{array}$ & $\begin{array}{c}\text { Biodiversität, Biologische } \\
\text { Vielfalt }\end{array}$ \\
\hline & & $\begin{array}{c}\text { environmental } \\
\text { conservation }\end{array}$ & Umweltschutz \\
\hline & & species protection & Artenschutz \\
\hline & & national park & Nationalpark \\
\hline
\end{tabular}




\section{Appendix 2 Literature review database}

\begin{tabular}{|c|c|c|}
\hline Reference & Category & Term usage \\
\hline $\begin{array}{c}\text { Ascher, D., and W. Ascher. 2016. 'Inducing Better Stakeholder Searches for Environmental } \\
\text { Information Relevant to Coastal Conservation' in B. H. MacDonald, S. S. Soomai, E. M. De Santo, } \\
\text { and P. G. Wells (eds.) Science, Information, and Policy Interface for Effective Coastal and Ocean } \\
\text { Management. Boca Raton, USA: CRC Press. [online] URL: } \\
\text { https://library.oapen.org/bitstream/handle/20.500.12657/22973/9781498731706 text.pdf? sequence=1 }\end{array}$ & B & $\begin{array}{l}\text { filter } \\
\text { bubble }\end{array}$ \\
\hline $\begin{array}{l}\text { Bell, T. 2017. OPTIMISATION OF FUEL REDUCTION BURNING REGIMES FOR FUEL } \\
\text { REDUCTION, CARBON, WATER AND VEGETATION OUTCOMES: Annual project report } \\
\text { 2016-2017. Melbourne, Australia: Bushfire and Natural Hazards CRC. [online] URL: } \\
\underline{\text { https://www.bnhcrc.com.au/sites/default/files/managed/downloads/na10 bell with eu annual report }} \\
\underline{2016-2017-\mathrm{mpr} \text { approved.pdf }}\end{array}$ & B & $\begin{array}{l}\text { filter } \\
\text { bubble }\end{array}$ \\
\hline $\begin{array}{c}\text { Bentley, R., and M. O'Brien. 2015. Collective Behaviour, Uncertainty and Environmental Change. } \\
\text { Philosophical Transactions, Royal Society A 373:20140461. [online] URL: } \\
\underline{\text { http://dx.doi.org/10.1098/rsta.2014.0461 }}\end{array}$ & $\mathrm{C}$ & $\begin{array}{c}\text { echo } \\
\text { chamber }\end{array}$ \\
\hline 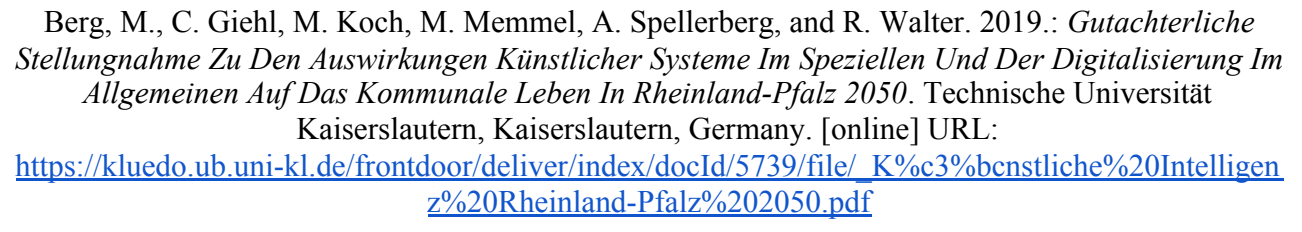 & $\mathrm{C}$ & both terms \\
\hline $\begin{array}{l}\text { Bernstein, F., L. Kaußen, and B. Stemmer. 2019. 'Online-Partizipation und Landschaft' in O. Kühne, } \\
\text { F. Weber, K. Berr, and C. Jenal (eds.) Handbuch Landschaft. Wiesbaden, Germany: Springer VS. } \\
\text { [online] URL: https://link.springer.com/chapter/10.1007/978-3-658-25746-0 } 43\end{array}$ & $\mathrm{C}$ & both terms \\
\hline $\begin{array}{l}\text { Clermont, H. 2018. 'The Underbelly of Economy versus Environment Conflicts: Detangling Sources } \\
\text { of Tension in Contentious Natural Resource Decisions', Dissertation, Royal Roads University, } \\
\text { Victoria, Canada. [online] URL: http://dx.doi.org/10.25316/IR-351 }\end{array}$ & B & both terms \\
\hline $\begin{array}{c}\text { Colston, N., and J. Thomas. 2019. Climate change skeptics teach climate literacy? A critical } \\
\text { discourse analysis of children's books. Journal of Science Communication 18(4):A02. [online] URL: } \\
\text { https://doi.org/10.22323/2.18040202 }\end{array}$ & B & $\begin{array}{c}\text { echo } \\
\text { chamber }\end{array}$ \\
\hline $\begin{array}{l}\text { Côté, I., and E. Darling. 2018. Scientists on Twitter: Preaching to the choir or singing from the } \\
\text { rooftops? FACETS Journal 3:682-694. [online] URL: https://doi.org/10.1139/facets-2018-0002 }\end{array}$ & B & both terms \\
\hline 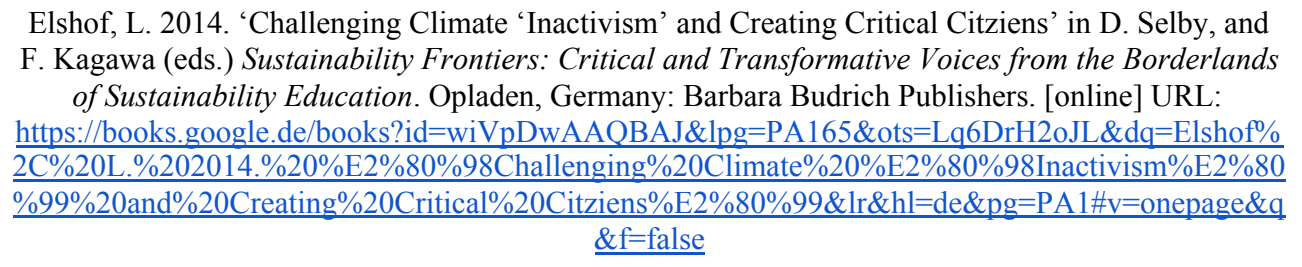 & B & $\begin{array}{l}\text { echo } \\
\text { chamber }\end{array}$ \\
\hline $\begin{array}{l}\text { Escher, T. 2013. Mobilisierung Zu Politischer Partizipation Durch Das Internet: Erwartungen, } \\
\text { Erkenntnisse Und Herausforderungen Der Forschung. Analyse \& Kritik 35(2):449-476. [online] } \\
\text { URL: http://www.analyse-und-kritik.net/Dateien/AusgID1 ak escher 2013.pdf }\end{array}$ & $\mathrm{C}$ & $\begin{array}{l}\text { filter } \\
\text { bubble }\end{array}$ \\
\hline $\begin{array}{l}\text { Fraser, H., and R. Fraser. 2017. What Rises Above the White Noise: the Possibility of Hearing Truth } \\
\text { in a Post-truth World. The Goose 16(1):7. [online] URL: } \\
\text { https://scholars.wlu.ca/thegoose/voll6/iss1/28 }\end{array}$ & B & $\begin{array}{c}\text { echo } \\
\text { chamber }\end{array}$ \\
\hline
\end{tabular}




\begin{tabular}{|c|c|c|}
\hline $\begin{array}{l}\text { Gleser, S., and S. Schneider. 2018. Meinungsmonitor Entwicklungspolitik 2018: Einstellungen Zu } \\
\text { Entwicklungszusammenarbeit Und Nachhaltiger Entwicklung. Deutsches Evaluierungsinstitut der } \\
\text { Entwicklungszusammenarbeit, Bonn, Germany. [online] URL: } \\
\text { https://www.ssoar.info/ssoar/bitstream/handle/document/58441/ssoar-2018-gleser et al-Meinungsm } \\
\text { onitor_Entwicklungspolitik_2018 Einstellungen_zu.pdf?sequence=1 }\end{array}$ & $\mathrm{C}$ & $\begin{array}{l}\text { filter } \\
\text { bubble }\end{array}$ \\
\hline $\begin{array}{l}\text { Hartl, P., and D. Ramsauer. 2017. Bundestagswahl 2017: Einblicke in das Tweetverhalten von } \\
\text { Politikern mit Netzwerkanalyse und Topic Modelling. Regensburg, Germany: Universität } \\
\text { Regensburg. [online] URL: } \underline{\text { https://dramsauer.me/pdf/btw.pdf }}\end{array}$ & B & $\begin{array}{l}\text { echo } \\
\text { chamber }\end{array}$ \\
\hline $\begin{array}{l}\text { Hermwille, L., and A. Siemons. 2018. What Makes an Ideal Global Stocktake? A Functional } \\
\text { Analysis. Dessau-Roßlau, Germany: Umweltbundesamt. [online] URL: } \\
\text { https://epub.wupperinst.org/frontdoor/deliver/index/docId/7141/file/7141 Hermwille.pdf }\end{array}$ & B & $\begin{array}{l}\text { echo } \\
\text { chamber }\end{array}$ \\
\hline $\begin{array}{l}\text { Hess, M. 2015. Network Frontier: Reframing Exploration and Exploitation In Internet Rhetoric. } \\
\text { Master Thesis, University of Oregon, Eugene, USA. [online] URL: } \\
\text { https://search.proquest.com/openview/13b492f432dc2e76e25b3752b6684616/1?pq-origsite=gscholar } \\
\underline{\& \mathrm{cbl}=18750 \& \text { diss }=\mathrm{y}}\end{array}$ & $\mathrm{C}$ & $\begin{array}{l}\text { filter } \\
\text { bubble }\end{array}$ \\
\hline $\begin{array}{l}\text { Hölderle, J. 2016. Expertise Social Media. Berlin, Germany: Technische Universität Berlin. [online] } \\
\text { URL: https://www.landschaft.tu-berlin.de/fileadmin/fg218/Forschung/Expertise-Social-Media.pdf }\end{array}$ & B & $\begin{array}{l}\text { filter } \\
\text { bubble }\end{array}$ \\
\hline 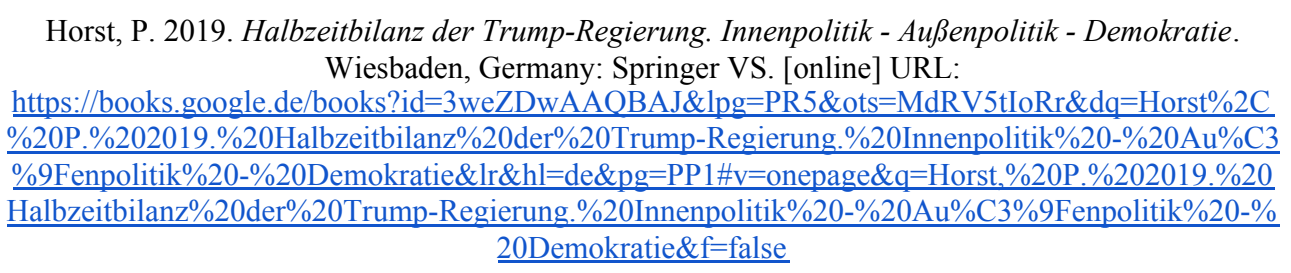 & $\mathrm{C}$ & $\begin{array}{l}\text { echo } \\
\text { chamber }\end{array}$ \\
\hline $\begin{array}{l}\text { Horton, P., and G. Brown. 2018. Integrating evidence, politics and society: a methodology for the } \\
\text { science-policy interface. Palgrave Communications 4(42):1-5. [online] URL: } \\
\text { https://www.nature.com/articles/s41599-018-0099-3 }\end{array}$ & $\mathrm{C}$ & $\begin{array}{l}\text { echo } \\
\text { chamber }\end{array}$ \\
\hline 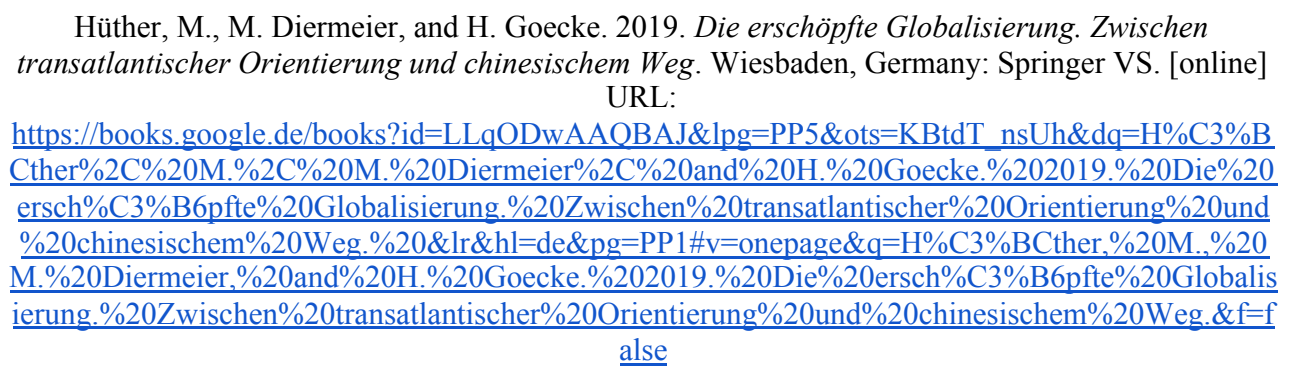 & $\mathrm{C}$ & $\begin{array}{l}\text { echo } \\
\text { chamber }\end{array}$ \\
\hline $\begin{array}{l}\text { Jasny, L., and D. Fisher. 2019. Echo chambers in climate science. Environmental Research } \\
\text { Communications 1(10):101003. [online] URL: https://doi.org/10.1088/2515-7620/ab491c }\end{array}$ & $\mathrm{A}$ & $\begin{array}{l}\text { echo } \\
\text { chamber }\end{array}$ \\
\hline $\begin{array}{l}\text { Kirchhof, P. 2018. Die Freiheit der Wissenschaft und ihre Abhängigkeit von Organisation, Finanzen } \\
\text { und öffentlicher Meinung. Studium Generale 2016 (2018): Manipulation:103-117. [online] URL: } \\
\qquad \underline{\text { https://doi.org/10.17885/heiup.studg.2018.1.23784 }}\end{array}$ & $\mathrm{C}$ & $\begin{array}{l}\text { echo } \\
\text { chamber }\end{array}$ \\
\hline $\begin{array}{c}\text { Klesper, B. 2019. 'Technologien Für Eine Bessere Welt - Corporate Responsibility bei der } \\
\text { Deutschen Telekom' in M. Englert, and A. Ternès (eds.) Nachhaltiges Management. Berlin, } \\
\text { Germany: Springer VS. [online] URL: } \\
\text { https://link.springer.com/chapter/10.1007/978-3-662-57693-9 } 36\end{array}$ & $\mathrm{C}$ & $\begin{array}{l}\text { filter } \\
\text { bubble }\end{array}$ \\
\hline $\begin{array}{c}\text { Koblischke, D. 2018. Virtual Reality, Augmented Reality und Tourismus: Eine kritische } \\
\text { Situationsanalyse des Substitutionspotenzials. Bachelor Thesis, Hochschule Harz, Wernigerode, } \\
\text { Germany. [online] URL: }\end{array}$ & $\mathrm{C}$ & $\begin{array}{c}\text { filter } \\
\text { bubble }\end{array}$ \\
\hline
\end{tabular}




\begin{tabular}{|c|c|c|}
\hline $\begin{array}{l}\text { https://d1wqtxts1xzle7.cloudfront.net/58131968/BACHELORARBEIT koblischke VR AR To } \\
\text { urismus freigegebene Version.pdf?1546873161=\&response-content-disposition=inline\%3B+filena } \\
\text { me\%3DVirtual Reality Augmented Reality and To.pdf\&Expires=1612633368\&Signature=bliYd5 } \\
\text { Hwx4SfS4iskiOwqVCyIGtFOMAmSdqAxa9RRVdJpvM0M-zuxF0mAgeA623M7U3ehe8N4ggVvF } \\
\text { lpXSKsxhOSDVGCagqt9qfnL SLru3BmOQPVSzNbDCqxhzZTXpb4-9ijTO1YJkwh2Wcf-jVsOux } \\
\text { nOqYcuk1d8F-gvcR2fffv8CYwPwacZ5ZbECqFxQRjOhf-s4Gt7cKJ7MWaX1bkOS711Bgutan7H1b } \\
\text { UqD7b5aJKcMry4hEUxIbSDCFPmua1cy6bbfmux1qJZ0wXU9azNYkgAsIFUCThCZ4KcEcJC-uLt } \\
\text { NgKG9c1YTrTmZwVsD8WYMA6Np4Z1RQtREWiH7D-g \&Key-Pair-Id=APKAJLOHF5GGSL } \\
\underline{\text { RBV4ZA }}\end{array}$ & & \\
\hline $\begin{array}{c}\text { Stemmer, B., and L. Kaußen. 2018. ‘Partizipative Methoden der Landschafts(bild)bewertung - Was } \\
\text { soll das bringen?’ in O. Kühne, and F. Weber (eds.) Bausteine der Energiewende. Wiesbaden, } \\
\text { Germany: Springer VS. [online] URL: } \\
\text { https://link.springer.com/chapter/10.1007/978-3-658-19509-0_24 }\end{array}$ & $\mathrm{C}$ & both terms \\
\hline $\begin{array}{c}\text { Madzwamuse, M., E. Rihoy, and M. Louis. 2020. Contested Conservation: Implications for Rights, } \\
\text { Democratization, and Citizenship in Southern Africa. Development 63:67-73. [online] URL: } \\
\underline{\text { https://doi.org/10.1057/s41301-020-00237-1 }}\end{array}$ & B & $\begin{array}{l}\text { echo } \\
\text { chamber }\end{array}$ \\
\hline $\begin{array}{l}\text { Matthews, B. 2017. Anti-Hierarchical Culture in Media-Based Creative Collectives: Sketching } \\
\text { Originary Analyses. Anthropoetics the Journal of Generative Anthropology 22(2):1-17. [online] } \\
\text { URL: } \underline{\text { https://researchdirect.westernsydney.edu.au/islandora/object/uws:42720/datastream/PDF/view }}\end{array}$ & $\mathrm{C}$ & $\begin{array}{c}\text { filter } \\
\text { bubble }\end{array}$ \\
\hline $\begin{array}{l}\text { Metson, T. 2018. 'Rampant Development in a Park of the People: Save Pirin and Lessons in the } \\
\text { Resistance against Neoliberalism', Master Thesis, Lund University, Lund, Sweden. [online] URL: } \\
\text { http://lup.lub.lu.se/luur/download?func=downloadFile\&recordOId=8963828\&fileOId=8963829 }\end{array}$ & B & both terms \\
\hline $\begin{array}{c}\text { Ortner, H. 2014. 'Zu viel Information? Kognitionswissenschaftliche und linguistische Aspekte der } \\
\text { Datenflut' in H. Ortner, D. Pfurtscheller, A. Wiesinger, and M. Rizzolli (eds.) Datenflut und } \\
\text { Informationskanäle. Innsbruck, Austria: Innsbruck University Press. [online] URL: } \\
\underline{\text { https://doi.org/10.25969/mediarep/928 }}\end{array}$ & $\mathrm{C}$ & both terms \\
\hline $\begin{array}{l}\text { Osburg, T. 2017. 'Sustainability in a Digital World Needs Trust' in T. Osburg, and C. Lohrmann } \\
\text { (eds.) Sustainability in a Digital World. Cham, Germany: Springer VS. [online] URL: } \\
\text { https://www.thomasosburg.de/wp-content/uploads/2017/07/SDW Content.pdf\#page=23 }\end{array}$ & $\mathrm{C}$ & $\begin{array}{l}\text { filter } \\
\text { bubble }\end{array}$ \\
\hline $\begin{array}{l}\text { Paulo, N. 2018. Die Rationalisierung postfaktischen Denkens. BEHEMOTH - A Journal on } \\
\text { Civilisation 11(2):55-73. [online] URL: https://doi.org/10.6094/behemoth.2018.11.2.988 }\end{array}$ & B & both terms \\
\hline $\begin{array}{l}\text { Pilkington, C. 2016. 'Deconstructing the Modern Research Paper: A Case Study', Undergraduate } \\
\text { Honours Degree, Dalhousie University, Halifax, Nova Scotia, Canada. [online] URL: } \\
\text { https://static1.squarespace.com/static/5b3babac70e802454aede034/t/5b5f419d0e2e726a186be180/15 } \\
\underline{32969377057 / \text { Pilkington UGThesis 160424.pdf }}\end{array}$ & B & $\begin{array}{l}\text { echo } \\
\text { chamber }\end{array}$ \\
\hline $\begin{array}{l}\text { Quitzau, J. 2018. Wirtschaftlicher Boom - Gesellschaftliche Spannungen: Ursachen und } \\
\text { wirtschaftspolitische Implikationen. Hamburg, Germany: Berenberg Makro. [online] URL: } \\
\text { https://www.berenberg.de/files/MacroNews2018/180522 Gesellschaftlicher\%20Zusammenhalt.pdf }\end{array}$ & $\mathrm{C}$ & both terms \\
\hline $\begin{array}{l}\text { Schmidt, J., L. Merten, U. Hasebrink, I. Petrich, and A. Rolfs. (eds.) 2017. Zur Relevanz von } \\
\text { Online-Intermediären für die Meinungsbildung. Arbeitspapiere des Hans-Bredow-Instituts Nr. } 40 . \\
\text { Hamburg, Germany: Verlag Hans-Bredow-Institut. [online] URL: } \\
\underline{\text { https://epub.sub.uni-hamburg.de/epub/volltexte/2017/74701/pdf/67256764e92e34539343a8c77a0215 }} \\
\underline{\text { bd96b35823.pdf }}\end{array}$ & $\mathrm{C}$ & both terms \\
\hline $\begin{array}{c}\text { Schweiger, W. 2017. Der (des)informierte Bürger im Netz: Wie soziale Medien die Meinungsbildung } \\
\text { verändern. Wiesbaden, Germany: Springer VS. [online] URL: } \\
\text { https://link.springer.com/chapter/10.1007/978-3-658-16058-6 } 4\end{array}$ & $\mathrm{C}$ & both terms \\
\hline $\begin{array}{l}\text { Sherren, K. 2020. 'From climax thinking toward a non-equilibrium approach to public good } \\
\text { landscape change' (Preprint) in J. Jacquet, J. Haggerty, and G. Theodori Energy Impacts: A } \\
\text { Multidisciplinary Exploration of North American Energy Development. Social Ecology Press \& Utah }\end{array}$ & $\mathrm{C}$ & $\begin{array}{l}\text { echo } \\
\text { chamber }\end{array}$ \\
\hline
\end{tabular}


State University Press. [online] URL:

https://www.researchgate.net/profile/Kate Sherren/publication/331940609 From climax thinking t oward a non-equilibrium approach to public good landscape change/links/5c94263945851506d7 22302f/From-climax-thinking-toward-a-non-equilibrium-approach-to-public-good-landscape-change. pdf

Theile, S. 2018. 'Social Media: Chancen und Herausforderungen für die räumliche Planung und Mitwirkung', Dissertation, Universität Kassel, Kassel, Germany. [online] URL: https://d-nb.info/1174922133/34

Titeca, K., and P. Edmond. 2019. Outside the Frame: Looking Beyond the Myth of Garamba's LRA Ivory-Terrorism Nexus. Conservation and Society 17(3):258-269. [online] URL: https://www.jstor.org/stable/26677962

Walter, S., M. Brüggemann, and S. Engesser. 2018. Echo Chambers of Denial: Explaining User comments on climate change. Environmental Communication 12(2):204-217. [online] URL: https://www.researchgate.net/profile/Michael Brueggemann/publication/341313337 Echo Chamber $\mathrm{s}$ of Denial Explaining User Comments on Climate Change View/links/5eba65e492851cd50dab 6608/Echo-Chambers-of-Denial-Explaining-User-Comments-on-Climate-Change-View.pdf

Waters, K. 2019. 'The Influence of Social Media Interactions on Perceptions of and Attitudes Toward Mexican Gray Wolves', Master Thesis, The University of Arizona, Arizona, Tucson. [online] URL:

https://repository.arizona.edu/bitstream/handle/10150/634268/azu etd 17332 sip1 m.pdf?sequence $=1 \&$ is Allowed $=\mathrm{y}$

Zegers, L. 2018. 'STUCK IN DENIAL VERSUS MOVING WITH SCIENCE: CLIMATE CHANGE DISCOURSES AND THE INFLUENCE OF THE DENIAL MACHINE ON LEFT AND

B both terms

RIGHT NEWS MEDIA', Master Thesis, Leiden University, Leiden, Netherlands. [online] URL: https://openaccess.leidenuniv.nl/bitstream/handle/1887/57935/20180118\%20MA\%20thesis\%20Luuk $\% 20$ Zegers $\% 20$ Final $\% 20$ Version.pdf? sequence $=1$ 
Appendix 3 Expert survey form

Fig. A2.1 Expert survey original form

\section{* Erforderlich}

\section{Naturschutz im Netz \\ Studienprojekt des Fachgebietes Landschaftsplanung und Landschaftsentwicklung}

\section{Filterblasen \& digitale Echokammern}

Seit einiger Zeit wird viel über die Auswirkungen digitaler Mediennutzung diskutiert. Unter anderem geht es darum, dass Nutzer*innen hauptsächlich mit Inhalten, die ihren eigenen Interessen und Ansichten entsprechen, in Kontakt kommen. Eine mögliche Folge ist, dass sich gesellschaftliche Gruppen immer mehr ausdifferenzieren und weniger untereinander austauschen. Als Ursache bzw. Ausdruck dieser Entwicklung werden „Filterblasen“ und „Echokammern“ genannt.

Der Begriff „Filterblase" stammt aus den Medienwissenschaften und beschreibt ein digitales Phänomen, bei dem Filteralgorithmen den Nutzer*innen individuell zugeschnittene Informationen bereitstellen. Das Konzept „Echokammer" stammt aus den Kommunikationswissenschaften. Durch den virtuellen Umgang mit Gleichgesinnten kommt es zur gegenseitigen Bestärkung der eigenen Meinung und einer Verengung der Weltsicht.

Ziel dieser Umfrage ist es, zu untersuchen, inwieweit Filterblasen und digitale Echokammern sowie deren mögliche Auswirkungen für den Naturschutz relevant sind.

Name (ausschließlich für eventuelle

Rückfragen):

Einrichtung: *

1. Die Begriffe „Filterblase" und „Echokammer" waren mir vorher bereits bekannt. Markieren Sie nur ein Oval.

Nein

Ja, der Begriff „Filterblase"

Ja, der Begriff „Echokammer"

Ja, beide Begriffe 
2. Filterblasen und/oder digitale Echokammern können für den Naturschutz relevant sein.

Markieren Sie nur ein Oval.

Nein

Ja, und zwar wie folgt:

3. Filterblasen und/oder digitale Echokammern waren in meinem beruflichen Kontext schon relevant.

Markieren Sie nur ein Oval.

Nein

$\mathrm{Ja}$, und zwar wie folgt:

4. Der Naturschutz sollte Filterblasen und/oder digitale Echokammern in seiner Arbeit berücksichtigen.

Markieren Sie nur ein Oval.

Nein, weil

Ja, weil

5. Die Berücksichtigung von Filterblasen und/oder digitalen Echokammern im Naturschutz könnte wie folgt aussehen:

6. Zur Thematik „Filterblasen und digitale Echokammern im Naturschutz" fällt mir darüber hinaus Folgendes ein:

Mit Absenden des Formulars stimmen Sie der Nutzung Ihrer anonymisierten Umfragedaten zu. 
Fig. A2.1 Expert survey translated form

*required

\section{Filter bubbles and digital echo chambers}

For some time now, there has been much discussion about the effects of digital media usage. Among other things, it is discussed that users mainly come into contact with content that corresponds with their own interests and views. One possible consequence is that social groups become increasingly differentiated and exchange information less with each other. "Filter bubbles" and "echo chambers" are considered to be the cause or manifestation of this development."

The term "filter bubble" comes from media studies and describes a digital phenomenon in which filter algorithms provide the user with individually customized information. The concept "echo chamber" originates from communication sciences. Through the virtual contact with like-minded people, a mutual strengthening of the own opinion and a narrowing of the world view take place.

The aim of this survey is to investigate to what extent filter bubbles and digital echo chambers and their possible effects are relevant for nature conservation.

Name (exclusively for potential follow-up questions):

Institution: *

1. The terms "echo chamber" and "filter bubble" were already familiar to me before.

Mark only one oval

No

Yes, the term "filter bubble"

Yes, the term "echo chamber"

Yes, both terms

2. Digital echo chambers and/or filter bubbles may be relevant for nature conservation.

Mark only one oval

No

Yes, in the following way: 
3. Digital echo chambers and/or filter bubbles were already relevant in my professional context.

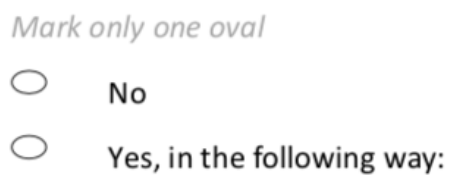

4. Nature conservation should take digital echo chambers and/or filter bubbles into account in its work.

\section{Mark only one oval}

No, because

Yes, because

5. The consideration of filter bubbles and/or digital echo chambers in nature conservation could be as follows:

6. On the subject of "filter bubbles and digital echo chambers in nature conservation", the following also comes to my mind:

By submitting the form, you agree to the use of your anonymized survey data. 
Appendix 4 Example for the thematic analysis approach

\section{Divide data into sections}

Firstly, all responses recorded through the expert survey were split into answer sections. This example was split into five sections.

Many possibilities, since nature conservation is also a very diverse topic in itself. In general, information work and sensitization must be more widespread and not only reach people who already have an affinity for nature conservation. In addition, a platform must be provided for the exchange of positions (e. g. public panel discussions on controversial topics). The objectification of often emotionally or ideologically charged discussions (topics such as wolves, lignite, designation of protected areas, wind power, ...) should also become more of a focus of nature conservation work.

\section{Identify patterns}

Patterns of similar or identical topics were identified. Within this example, four different topics occurred.

Many possibilities s since nature conservation is also a a very diverse topic in itself. In general, information work and sensitization must be more widespread and not only reach people who already have an affinity for nature conservation. In addition, ia platform must be provided for the exchange of 'positions (e. g. public panel discussions on controversial topics). The objectification of often emotionally or ideologically charged discussions (topics such as wolves, lignite, designation of protected areas, wind power, ...) should also become more of a focus of nature conservation work.

\section{Define codes}

The answer sections of all participants were clustered and assigned to the identified patterns. Out of those, different codes were phrased to summarize the statements.

\begin{tabular}{|c|c|}
\hline iCode $\overline{A_{j}}$ & If and how echo chambers and filter bubbles should be considered in nature conservation \\
\hline Code B & $\begin{array}{l}\text { Echo chambers and filter bubbles can hinder nature conservation communication } \\
\text { processes and make it hard to reach people }\end{array}$ \\
\hline Code $\mathrm{C}_{i}$ & Echo chambers and filter bubbles are tied to technological and digital factors \\
\hline Code D & $\begin{array}{l}\text { There are practical examples where echo chambers and filter bubbles affect nature } \\
\text { conservation }\end{array}$ \\
\hline
\end{tabular}




\section{Identify themes}

The identified codes were in turn combined into overarching themes.

\begin{tabular}{|c|c|}
\hline $\begin{array}{l}\text { How echo chambers and } \\
\text { filter bubbles can or } \\
\text { cannot be handled }\end{array}$ & $\begin{array}{l}\text { If and how echo chambers and filter bubbles should be } \\
\text { jconsidered in nature conservation }\end{array}$ \\
\hline \multirow{2}{*}{$\begin{array}{l}\text { Echo chambers and filter } \\
\text { bubbles are of relevance in } \\
\text { the communication of } \\
\text { nature conservation topics }\end{array}$} & $\begin{array}{l}\text { Echo chambers and filter bubbles can hinder } \\
\text { nature conservation communication processes } \\
\text { and make it hard to reach people }\end{array}$ \\
\hline & $\begin{array}{l}\text { There are practical examples where echo chambers and } \\
\text { filter bubbles affect nature conservation }\end{array}$ \\
\hline $\begin{array}{l}\text { Echo chambers and filter } \\
\text { bubbles are tied to } \\
\text { different societal factors }\end{array}$ & $\begin{array}{l}\text { Echo chambers and filter bubbles are tied to } \\
\text { 'technological and digital factors }\end{array}$ \\
\hline
\end{tabular}


Appendix 5 Expert survey data

\begin{tabular}{|c|c|c|c|c|c|}
\hline $\begin{array}{l}\text { 1. Die Begriffe } \\
\text { „Filterblase" und } \\
\text { „Echokammer" } \\
\text { waren mir vorher } \\
\text { bereits bekannt. }\end{array}$ & $\begin{array}{l}\text { 2. Filterblasen und/oder } \\
\text { digitale Echokammern } \\
\text { können für den } \\
\text { Naturschutz relevant } \\
\text { sein. }\end{array}$ & $\begin{array}{l}\text { 3. Filterblasen } \\
\text { und/oder digitale } \\
\text { Echokammern waren } \\
\text { in meinem } \\
\text { beruflichen Kontext } \\
\text { schon relevant. }\end{array}$ & $\begin{array}{l}\text { 4. Der Naturschutz } \\
\text { sollte Filterblasen } \\
\text { und/oder digitale } \\
\text { Echokammern in } \\
\text { seiner Arbeit } \\
\text { berücksichtigen. }\end{array}$ & $\begin{array}{l}\text { 5. Die Berücksichtigung } \\
\text { von Filterblasen } \\
\text { und/oder digitalen } \\
\text { Echokammern im } \\
\text { Naturschutz könnte wie } \\
\text { folgt aussehen: }\end{array}$ & $\begin{array}{l}\text { 6. Zur Thematik } \\
\text { „Filterblasen und } \\
\text { digitale Echokammern } \\
\text { im Naturschutz" fällt } \\
\text { mir darüber hinaus } \\
\text { Folgendes ein: }\end{array}$ \\
\hline $\begin{array}{l}\text { Ja, der Begriff } \\
\text { „Echokammer" }\end{array}$ & $\begin{array}{l}\text { Ja, und zwar wie folgt: } \\
\text { Schwierig. Einerseits } \\
\text { verstärkt es die Infos in } \\
\text { der eigenen Community, } \\
\text { andererseits werden die } \\
\text { Abgrenzungen zwischen } \\
\text { den Echokammern } \\
\text { immer härter. }\end{array}$ & Nein & $\begin{array}{c}\text { (Hinweis der } \\
\text { Autorinnen: keine } \\
\text { Antwort auf Multiple } \\
\text { Choice Frage } \\
\text { gegeben) Ich bin da } \\
\text { noch sehr } \\
\text { unentschieden. Man } \\
\text { sollte sich der } \\
\text { Echokammern } \\
\text { bewusst sein, ich } \\
\text { sehe aber gerade } \\
\text { nicht, dass ich sie } \\
\text { bewusst in meine } \\
\text { Arbeit einbauen } \\
\text { könnte oder wollte. } \\
\text { Der (anonymisiert) } \\
\text { ist zudem sehr wenig } \\
\text { in social media } \\
\text { unterwegs. Z. Zt. nur } \\
\text { bei Twitter. }\end{array}$ & s. Frage 4. & \\
\hline
\end{tabular}




\begin{tabular}{|c|c|c|c|c|}
\hline Ja, beide Begriffe & $\begin{array}{l}\text { Ja, und zwar wie folgt: } \\
\text { Beeinflussung der } \\
\text { öffentlichen Meinung } \\
\text { und ggf. Verstärkung von } \\
\text { Vorurteilen bestimmter } \\
\text { Interessengruppen (bspw. } \\
\text { Naturschutz behindert } \\
\text { Windkraftausbau) }\end{array}$ & $\begin{array}{l}\text { Ja, und zwar wie } \\
\text { folgt: }\end{array}$ & $\begin{array}{l}\text { Ja, weil: Naturschutz } \\
\text { ist auf hinreichende } \\
\text { gesellschaftliche } \\
\text { Akzeptanz } \\
\text { angewiesen ist. }\end{array}$ & $\begin{array}{l}\text { Vielleicht noch mehr } \\
\text { digitale Medien nutzen, } \\
\text { um erfolgreiche } \\
\text { Maßnahmen bspw. im } \\
\text { Artenschutz zu } \\
\text { dokumentieren oder um } \\
\text { auf Probleme } \\
\text { aufmerksam zu machen. } \\
\text { Dabei muss aber } \\
\text { sorgfältig abgewogen } \\
\text { werden, welche Kanäle } \\
\text { genutzt werden sollten. } \\
\text { Bspw. Kommunikation } \\
\text { über Facebook würde } \\
\text { ich aufgrund fehlender } \\
\text { Datensicherheit und } \\
\text { fehlenden } \\
\text { gesellschaftlichen } \\
\text { Verantwortungsbewusst } \\
\text { sein der } \\
\text { Plattformbetreiber } \\
\text { grundsätzlich ablehnen. }\end{array}$ \\
\hline $\begin{array}{l}\text { Ja, der Begriff } \\
\text { „Filterblase" }\end{array}$ & Ja, und zwar wie folgt: & Nein & Ja, weil: & \\
\hline Ja, beide Begriffe & $\begin{array}{l}\text { Ja, und zwar wie folgt: } \\
\text { z.B. bei den Themen } \\
\text { Wolfsmanagement, } \\
\text { Landwirtschaft (z.B. } \\
\text { Düngerecht) }\end{array}$ & Nein, nicht direkt & $\begin{array}{l}\text { Ja, weil: die } \\
\text { Naturschutzarbeit } \\
\text { u.U. erschwert } \\
\text { werden kann. }\end{array}$ & $\begin{array}{l}\text { Möglichst gute und } \\
\text { vorausschauende } \\
\text { Kommunikationskonze } \\
\text { pte und } \\
\text { Öffentlichkeitsarbeit zu }\end{array}$ \\
\hline
\end{tabular}




\begin{tabular}{|c|c|c|c|c|}
\hline & & & & $\begin{array}{l}\text { allen Themen von } \\
\text { Naturschutz und } \\
\text { Landschaftspflege }\end{array}$ \\
\hline Ja, beide Begriffe & $\begin{array}{c}\text { Ja, und zwar wie folgt: } \\
\text { Weil sie } \\
\text { konsensorientierte } \\
\text { Dialoge und Lösungen } \\
\text { erschweren }\end{array}$ & Nein & $\begin{array}{c}\text { Ja, weil: siehe Frage } \\
2\end{array}$ & $\begin{array}{l}\text { Gezieltes Ansprechen } \\
\text { anderer Echokammern }\end{array}$ \\
\hline Ja, beide Begriffe & $\begin{array}{l}\text { Ja, und zwar wie folgt: } \\
\text { Sowohl eigene } \\
\text { Fanatisierung als auch } \\
\text { die der Gegner } \\
\text { (Landnutzer, } \\
\text { Autofahrer...) }\end{array}$ & $\begin{array}{c}\text { Ja, und zwar wie } \\
\text { folgt: Shitstorm von } \\
\text { Landwirten, } \\
\text { Tierschützern aus } \\
\text { deren Filterblasen } \\
\text { heraus }\end{array}$ & $\begin{array}{l}\text { Ja, weil: vermeiden } \\
\text { bzw. professionell } \\
\text { begegnen }\end{array}$ & $\begin{array}{l}\text { Schulung der eigenen } \\
\text { Leute, Aufbau } \\
\text { sachlicher } \\
\text { Informationsangebote, } \\
\text { Vertrauenswerbung mit } \\
\text { "bunten Meldungen" }\end{array}$ \\
\hline Ja, beide Begriffe & $\begin{array}{l}\text { Ja, und zwar wie folgt: } \\
\text { genauso relevant wie in } \\
\text { allen Bereichen der } \\
\text { Gesellschaft: Wenn } \\
\text { Menschen nicht mehr mit } \\
\text { Naturschutzthemen/-ziele } \\
\text { n erreicht werden, weil } \\
\text { sie sich medial in } \\
\text { "Filterblasen" befinden, } \\
\text { ist dies für den } \\
\text { Naturschutz ein Problem. }\end{array}$ & Nein & $\begin{array}{l}\text { Ja, weil: wir das Ziel } \\
\text { haben müssen, } \\
\text { möglichst alle } \\
\text { Bevölkerungsgruppe } \\
\text { n/alle Menschen mit } \\
\text { Naturschutzthemen } \\
\text { zu erreichen. Die } \\
\text { Frage ist natürlich, } \\
\text { ob der Naturschutz } \\
\text { etwas Spezielles tun } \\
\text { kann. }\end{array}$ & $\begin{array}{l}\text { Wichtig ist auch in } \\
\text { diesem Kontext die } \\
\text { Zusamemarbeit mit } \\
\text { Kitas/Schulen. Hier } \\
\text { können alle Kinder aller } \\
\text { Bevölkerungsgruppen } \\
\text { direkt erreicht werden } \\
\text { und die Kinder sind } \\
\text { (hoffentlich) nicht nicht } \\
\text { in den "Filterblasen" } \\
\text { "gefangen". Wenn die } \\
\text { Kinder früh erreicht } \\
\text { werden, steigt die } \\
\text { Chance (so die } \\
\text { Hoffnung), dass sie }\end{array}$ \\
\hline
\end{tabular}




\begin{tabular}{|c|c|c|c|c|c|}
\hline & & & & $\begin{array}{l}\text { später von sich aus } \\
\text { Kontakt zu } \\
\text { Natur/Verständnis für } \\
\text { Naturschutz bewahren } \\
\text { und (hoffentlich) aus } \\
\text { sich heraus, die } \\
\text { "Filterblasen" } \\
\text { verlassen. Auch für } \\
\text { Erwachsene bleibt ein } \\
\text { entscheidender Punkt, } \\
\text { sie mit direkten } \\
\text { Erlebnissen } \\
\text { anzusprechen. }\end{array}$ & \\
\hline Ja, beide Begriffe & $\begin{array}{c}\text { Ja, und zwar wie folgt: } \\
\text { Entfernung von der } \\
\text { Zielgruppe; } \\
\text { Fehleinschätzungen zur } \\
\text { Wirkung von } \\
\text { Argumenten... }\end{array}$ & Keine Antwort & Keine Antwort & nicht pauschalisierbar & $\begin{array}{l}\text { Merkwürdige } \\
\text { Umfrage... }\end{array}$ \\
\hline
\end{tabular}




\begin{tabular}{|c|c|c|c|c|c|}
\hline & & & & $\begin{array}{l}\text { Menschen erreichen. } \\
\text { Zudem muss eine } \\
\text { Plattform für den } \\
\text { Austausch von } \\
\text { Positionen geboten } \\
\text { werden (bspw. } \\
\text { öffentliche } \\
\text { Podiumsdiskussionen } \\
\text { zu Streitthemen). Auch } \\
\text { die Versachlichung von } \\
\text { oft emotional oder } \\
\text { ideologische } \\
\text { aufgeladenen } \\
\text { Diskussionen (Themen } \\
\text { Wolf, Braunkohle, } \\
\text { Ausweisung von } \\
\text { Schutzgebieten, } \\
\text { Windkraft,...) sollte } \\
\text { mehr in den Fokus der } \\
\text { Naturschutzarbeit } \\
\text { rücken. }\end{array}$ & $\begin{array}{c}\text { analogen Filterblasen } \\
\text { bewegen, wenn sie nur } \\
\text { gezielt } \\
\text { Meinungskonforme } \\
\text { Informationen suchen? }\end{array}$ \\
\hline $\begin{array}{l}\text { Ja, der Begriff } \\
\text { „Filterblase" }\end{array}$ & $\begin{array}{l}\text { Ja, und zwar wie folgt: } \\
\text { Ja, da dadurch keine } \\
\text { neuen Zielgruppen } \\
\text { erreicht werden können, } \\
\text { die es zu sensibilisieren } \\
\text { gilt. Gleichzeitig ist der } \\
\text { Austausch unter } \\
\text { "Gleichgesinnten" }\end{array}$ & $\begin{array}{l}\text { Ja, und zwar wie } \\
\text { folgt: Wir haben } \\
\text { Schwierigkeiten } \\
\text { neue Zielgruppen zu } \\
\text { erreichen, die sich } \\
\text { noch nicht mit } \\
\text { Naturschutzthemen } \\
\text { beschäftigen. }\end{array}$ & $\begin{array}{l}\text { Ja, weil: einerseits } \\
\text { Motivation und } \\
\text { Engagement bestärkt } \\
\text { werden können } \\
\text { (siehe Fridays For } \\
\text { Future), andererseits } \\
\text { potenziell engagierte }\end{array}$ & $\begin{array}{c}\text { Die daraus } \\
\text { entstehenden Kanäle } \\
\text { können gezielt genutzt } \\
\text { werden um Kampagnen } \\
\text { zu starten, jedoch } \\
\text { sollten auch andere } \\
\text { Wege eingeschlagen }\end{array}$ & \\
\hline
\end{tabular}




\begin{tabular}{|c|c|c|c|c|c|}
\hline & $\begin{array}{l}\text { wichtig um das eigene } \\
\text { Engagement zu bestärken } \\
\text { und die Motivation für } \\
\text { Naturschutzarbeit } \\
\text { aufrecht zu erhalten. }\end{array}$ & $\begin{array}{l}\text { (Kommunen, } \\
\text { Unternehmen, junge } \\
\text { Erwachsene...) }\end{array}$ & $\begin{array}{l}\text { Personen nicht } \\
\text { erreicht werden. }\end{array}$ & $\begin{array}{l}\text { werden um weitere } \\
\text { Menschen zu erreichen. }\end{array}$ & \\
\hline Ja, beide Begriffe & $\begin{array}{l}\text { Ja, und zwar wie folgt: } \\
\text { Confirmation Bias: Wir } \\
\text { neigen wir dazu, } \\
\text { Informationen zu } \\
\text { bevorzugen, die mit den } \\
\text { eigenen Standpunkten } \\
\text { überein stimmen. } \\
\text { Gegenargumente werden } \\
\text { kaum zugelassen. }\end{array}$ & $\begin{array}{l}\text { Ja, und zwar wie } \\
\text { folgt: Ständig, in } \\
\text { unterschiedlichster } \\
\text { Form. Ich arbeite } \\
\text { unter anderem mit } \\
\text { Social Media. Zwei } \\
\text { Beispiele: } \\
\text { Verschwörungstheor } \\
\text { etiker, } \\
\text { AfD-Anhänger..., die } \\
\text { Postings } \\
\text { kommentieren. } \\
\text { Ich bin dieser Gefahr } \\
\text { aber auch selbst } \\
\text { ausgesetzt und muss } \\
\text { mich immer wieder } \\
\text { daran erinnern, nicht } \\
\text { nur einseitig } \\
\text { Informationen (u.a. } \\
\text { über abonnierte } \\
\text { Profile in den Feeds) } \\
\text { zu beziehen. }\end{array}$ & $\begin{array}{l}\text { Ja, weil: Klar! Es } \\
\text { gibt immer so viele } \\
\text { Facetten zu } \\
\text { berücksichtigen... }\end{array}$ & $\begin{array}{l}\text { Diskussionsforen, die } \\
\text { für alle offen sind/ } \\
\text { Gegenüberstellen von } \\
\text { Meinungen/ } \\
\text { Transparenz (u.a. im } \\
\text { Bezug auf Absender...) }\end{array}$ & $\begin{array}{c}\text { Jede Menge aber ich } \\
\text { habe gerade nicht viel } \\
\text { Zeit ;-) }\end{array}$ \\
\hline Ja, beide Begriffe & $\begin{array}{c}\text { Ja, und zwar wie folgt: } \\
\text { Wie in jedem }\end{array}$ & $\begin{array}{l}\text { Ja, und zwar wie } \\
\text { folgt: Diskussionen }\end{array}$ & $\begin{array}{l}\text { Ja, weil: } \\
\text { Nachhaltiger }\end{array}$ & $\begin{array}{l}\text { Immer wieder für sich } \\
\text { selbst neue Gedanken }\end{array}$ & $\begin{array}{l}\text { Es war schon immer } \\
\text { gefährlich, }\end{array}$ \\
\hline
\end{tabular}




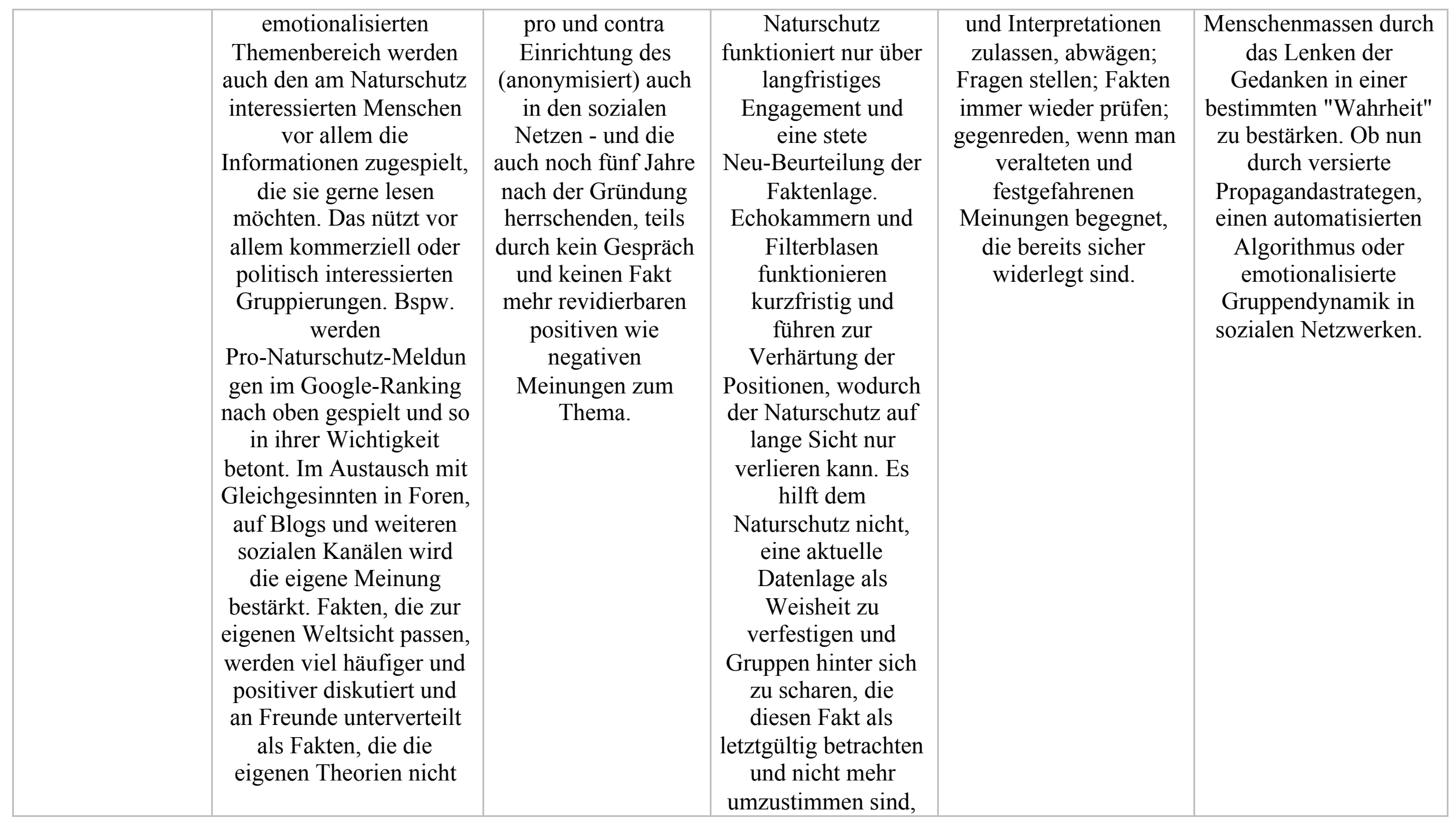




\begin{tabular}{|c|c|c|c|c|c|}
\hline & $\begin{array}{l}\text { stärken oder diesen sogar } \\
\text { widersprechen. }\end{array}$ & & $\begin{array}{c}\text { egal, wie die } \\
\text { Datenlage in der } \\
\text { Zukunft aussehen } \\
\text { mag und interpretiert } \\
\text { werden kann. } \\
\text { Deshalb sollte man } \\
\text { die Mechanismen } \\
\text { kennen, in der } \\
\text { eigenen Arbeit } \\
\text { vermeiden und so } \\
\text { gut wie möglich } \\
\text { verhindern, dass man } \\
\text { selbst } \\
\text { "betriebsblind" wird. }\end{array}$ & & \\
\hline $\begin{array}{l}\text { Ja, der Begriff } \\
\text { „Filterblase" }\end{array}$ & $\begin{array}{l}\text { Ja, und zwar wie folgt: } \\
\text { Filterblasen bzw. digitale } \\
\text { Echokammern sind für } \\
\text { alle gesellschaftlichen } \\
\text { Themen relevant, weil } \\
\text { Meinungen automatisiert } \\
\text { mithilfe von Algorithmen } \\
\text { erzeugt werden können, } \\
\text { wie hier eingangs bereits } \\
\text { beschrieben. Ein schönes } \\
\text { Beispiel ist der Erfolg } \\
\text { von Cambridge } \\
\text { Analytica. Es gibt viele } \\
\text { andere Beispiele - dieser } \\
\text { Fall ist jedoch so gut }\end{array}$ & $\begin{array}{l}\text { Ja, und zwar wie } \\
\text { folgt: In der } \\
\text { Elektromobilitätsbra } \\
\text { nche, (anonymisiert), } \\
\text { werden manchmal } \\
\text { die ökologischen } \\
\text { Folgen der } \\
\text { Elektromobilität } \\
\text { bewusst nicht aus } \\
\text { ganzheitlicher Sicht } \\
\text { betrachtet. Auch } \\
\text { wenn neue Batterien } \\
\text { (sog. Solid State } \\
\text { Batteries) } \\
\text { wahrscheinlich in }\end{array}$ & $\begin{array}{c}\text { Ja, weil: ... das } \\
\text { Bewusstsein/Wissen } \\
\text { darüber vielleicht die } \\
\text { Art der } \\
\text { Öffentlichkeitsarbeit } \\
\text { der } \\
\text { Naturschutzbewegun } \\
\text { g ändert. Ich sage } \\
\text { "vielleicht", weil } \\
\text { eine breite } \\
\text { Öffentlichkeit } \\
\text { erreicht werden soll, } \\
\text { die zu hohem Anteil } \\
\text { Plattformen nutzt, } \\
\text { die auf nicht }\end{array}$ & $\begin{array}{c}\text { Das ist aufgrund der } \\
\text { unter } 4 \text {. beschriebenen } \\
\text { Sachlage schwierig. } \\
\text { Nutzung von } \\
\text { ausschließlich Open } \\
\text { Source Lösungen führt } \\
\text { wieder zu Filterblasen } \\
\text { innerhalb der } \\
\text { Naturschutzgemeinde, } \\
\text { wenn auch Filterblasen } \\
\text { durch Algorithmen } \\
\text { (insb. durch Werbung) } \\
\text { nicht verstärkt } \\
\text { werden.BTW, es gibt es } \\
\text { übrigens zu sehr vielen }\end{array}$ & $\begin{array}{l}\text { Es gibt noch viel zu } \\
\text { sagen, den Kern der } \\
\text { Sache konnte ich aber } \\
\text { hoffentlich verständlich } \\
\text { transportieren :-) Wenn } \\
\text { nicht, gern Rückfragen. }\end{array}$ \\
\hline
\end{tabular}




\begin{tabular}{|c|c|c|c|}
\hline $\begin{array}{l}\text { dokumentiert, dass eine } \\
\text { Negierung dieses } \\
\text { Faktums nicht haltbar } \\
\text { ist.Durch gezielte } \\
\text { Botschaften unter } \\
\text { Anwendung } \\
\text { psychologischer } \\
\text { Methoden kann ebenfalls } \\
\text { der öffentliche Diskurs } \\
\text { über den Naturschutz } \\
\text { beeinflusst werden, z. B. } \\
\text { indem falsche Fakten } \\
\text { zum Klimawandel } \\
\text { massenhaft in sozialen } \\
\text { Medien verbreitet } \\
\text { werden.Ob das } \\
\text { demokratische Prozesse } \\
\text { sind wie im Beispiel von } \\
\text { Cambridge Analytca sind } \\
\text { oder der Naturschutz ist } \\
\text { irrelevant. Diese } \\
\text { Manipulation ist wie } \\
\text { Algorithmen selbst per } \\
\text { Definition agnostisch, d. } \\
\text { h. für beliebige } \\
\text { Anwendungsfälle } \\
\text { anwendbar. }\end{array}$ & $\begin{array}{l}\text { einigen Jahren von } \\
\text { den Laboren als } \\
\text { Lösung auf den } \\
\text { Markt kommt, } \\
\text { werden die } \\
\text { ökologische Folgen } \\
\text { der aktuellen, auf } \\
\text { Lithium basierten } \\
\text { Batterie-Technologie } \\
\text {, bewusst nicht } \\
\text { erwähnt oder } \\
\text { reduziert.Treiber } \\
\text { dafür ist natürlich } \\
\text { die Infragestellung } \\
\text { des } \\
\text { Geschäftsmodells } \\
\text { des eigenen } \\
\text { Unternehmens bzw. } \\
\text { der Branche, in der } \\
\text { nicht nur } \\
\text { Elektroautos, } \\
\text { sondern auch } \\
\text { Ladeinfrastruktur } \\
\text { und viel Technik die } \\
\text { Verkaufsprodukte } \\
\text { sind.In den sozialen } \\
\text { Medien dieser } \\
\text { Branche werden } \\
\text { daher bewusst }\end{array}$ & $\begin{array}{c}\text { kontrollierbaren } \\
\text { Algorithmen } \\
\text { basieren.Denn diese } \\
\text { sind nicht Open } \\
\text { Source, d. h. die } \\
\text { Technologie dahinter } \\
\text { (der "Source Code") } \\
\text { ist nicht open, also } \\
\text { nicht öffentlich und } \\
\text { damit nicht } \\
\text { einsehbar oder } \\
\text { änderbar. Leider } \\
\text { verwenden } \\
\text { allerdings der } \\
\text { Großteil der } \\
\text { Menschen dieses } \\
\text { sog. proprietären } \\
\text { Algorithmen/Dienste } \\
\text { wie an diesem } \\
\text { Google Sheet auch } \\
\text { zu sehen ist ;) } \\
\text { Dadurch haben wir } \\
\text { als Gesellschaft } \\
\text { kaum noch } \\
\text { Souveränität } \\
\text { (Kontrolle, Einfluss) } \\
\text { über Algorithmen im } \\
\text { Internet.Um die } \\
\text { breite Öffentlichkeit }\end{array}$ & $\begin{array}{l}\text { proprietären Diensten } \\
\text { Open Source } \\
\text { Alternativen. Leider } \\
\text { interessieren sich nur } \\
\text { wenige dafür, wie eben } \\
\text { auch hier Google Sheets } \\
\text { verwendet wird.IMHO } \\
\text { sollte man im } \\
\text { Naturschutz-Diskurs } \\
\text { Open Source Lösungen } \\
\text { präferieren, aber } \\
\text { trotzdem auch die nicht } \\
\text { offenen Plattformen } \\
\text { nutzen, um die breite } \\
\text { Öffentlichkeit zu } \\
\text { erreichen. }\end{array}$ \\
\hline
\end{tabular}




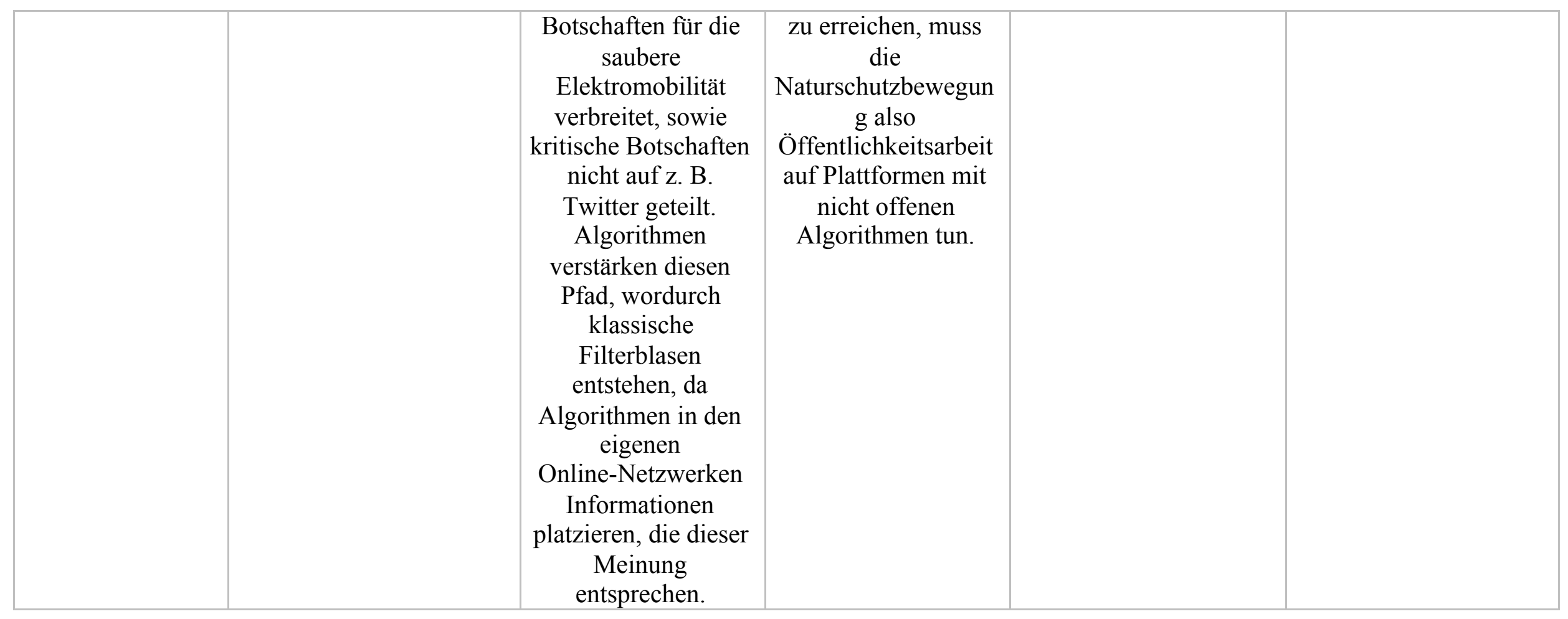


Appendix 6 Expert survey thematic analysis

\begin{tabular}{|c|c|c|c|}
\hline Theme & Codes & Count & Answer sections \\
\hline \multirow[t]{2}{*}{$\begin{array}{l}\text { Different groups } \\
\text { are affected by } \\
\text { echo chambers } \\
\text { and filter bubbles }\end{array}$} & $\begin{array}{c}\text { Nature conservation } \\
\text { proponents are affected by } \\
\text { echo chambers and filter } \\
\text { bubbles. }\end{array}$ & 9 & $\begin{array}{l}\text { Sowohl eigene Fanatisierung als auch die der Gegner | Da sie in beide Richtungen } \\
\text { (Pro und Contra Naturschutz) radikalisieren können | Wie in jedem emotionalisierten } \\
\text { Themenbereich werden auch den am Naturschutz interessierten Menschen vor allem } \\
\text { die Informationen zugespielt, die sie gerne lesen möchten | Shitstorm von Landwirten, } \\
\text { Tierschützern aus deren Filterblasen heraus | Ich bin dieser Gefahr aber auch selbst } \\
\text { ausgesetzt | Diskussionen pro und contra Einrichtung des Nationalparks auch in den } \\
\text { sozialen Netzen | einerseits Motivation und Engagement bestärkt werden können } \\
\text { (siehe Fridays For Future) | Nachhaltiger Naturschutz funktioniert nur über } \\
\text { langfristiges Engagement und eine stete Neu-Beurteilung der Faktenlage. } \\
\text { Echokammern und Filterblasen funktionieren kurzfristig und führen zur Verhärtung } \\
\text { der Positionen, wodurch der Naturschutz auf lange Sicht nur verlieren kann. Es hilft } \\
\text { dem Naturschutz nicht, eine aktuelle Datenlage als Weisheit zu verfestigen und } \\
\text { Gruppen hinter sich zu scharen, die diesen Fakt als letztgültig betrachten und nicht } \\
\text { mehr umzustimmen sind, egal, wie die Datenlage in der Zukunft aussehen mag und } \\
\text { interpretiert werden kann. Deshalb sollte man die Mechanismen kennen, in der } \\
\text { eigenen Arbeit vermeiden und so gut wie möglich verhindern, dass man selbst } \\
\text { "betriebsblind" wird. | Immer wieder für sich selbst neue Gedanken und } \\
\text { Interpretationen zulassen, abwägen; Fragen stellen; Fakten immer wieder prüfen; } \\
\text { gegenreden, wenn man veralteten und festgefahrenen Meinungen begegnet, die bereits } \\
\text { sicher widerlegt sind. }\end{array}$ \\
\hline & $\begin{array}{l}\text { Nature conservation } \\
\text { "adversaries" and persons } \\
\text { without a stance on nature } \\
\text { conservation are affected } \\
\text { by echo chambers and } \\
\text { filter bubbles. }\end{array}$ & 6 & $\begin{array}{l}\text { Sowohl eigene Fanatisierung als auch die der Gegner | Wenn Menschen nicht mehr } \\
\text { mit Naturschutzthemen/-zielen erreicht werden, weil sie sich medial in "Filterblasen" } \\
\text { befinden | Da sie in beide Richtungen (Pro und Contra Naturschutz) radikalisieren } \\
\text { können | Shitstorm von Landwirten, Tierschützern aus deren Filterblasen heraus | } \\
\text { Diskussionen pro und contra Einrichtung des Nationalparks auch in den sozialen } \\
\text { Netzen | Kinder sind (hoffentlich) nicht nicht in den "Filterblasen" "gefangen". }\end{array}$ \\
\hline
\end{tabular}




\begin{tabular}{|c|c|c|c|}
\hline $\begin{array}{l}\text { How echo chambers } \\
\text { and filter bubbles } \\
\text { can or cannot be } \\
\text { handled. }\end{array}$ & $\begin{array}{l}\text { Echo chambers and filter } \\
\text { bubbles and their effects } \\
\text { can be deliberately } \\
\text { utilized. }\end{array}$ & 9 & $\begin{array}{l}\text { Beeinflussung der öffentlichen Meinung | werden auch den am Naturschutz } \\
\text { interessierten Menschen vor allem die Informationen zugespielt, die sie gerne lesen } \\
\text { möchten | Filterblasen bzw. digitale Echokammern sind für alle gesellschaftlichen } \\
\text { Themen relevant, weil Meinungen automatisiert mithilfe von Algorithmen erzeugt } \\
\text { werden können | Durch gezielte Botschaften unter Anwendung psychologischer } \\
\text { Methoden kann ebenfalls der öffentliche Diskurs über den Naturschutz beeinflusst } \\
\text { werden | Diese Manipulation ist wie Algorithmen selbst per Definition agnostisch | } \\
\text { werden manchmal die ökologischen Folgen der Elektromobilität bewusst nicht aus } \\
\text { ganzheitlicher Sicht betrachtet. Auch wenn neue Batterien (sog. Solid State Batteries) } \\
\text { wahrscheinlich in einigen Jahren von den Laboren als Lösung auf den Markt kommt, } \\
\text { werden die ökologische Folgen der aktuellen, auf Lithium basierten } \\
\text { Batterie-Technologie, bewusst nicht erwähnt oder reduziert. | werden daher bewusst } \\
\text { Botschaften für die saubere Elektromobilität verbreitet, sowie kritische Botschaften } \\
\text { nicht auf z. B. Twitter geteilt | Die daraus entstehenden Kanäle können gezielt genutzt } \\
\text { werden um Kampagnen zu starten | Es war schon immer gefährlich, Menschenmassen } \\
\text { durch das Lenken der Gedanken in einer bestimmten "Wahrheit" zu bestärken. Ob nun } \\
\text { durch versierte Propagandastrategen, einen automatisierten Algorithmus oder } \\
\text { emotionalisierte Gruppendynamik in sozialen Netzwerken. }\end{array}$ \\
\hline
\end{tabular}




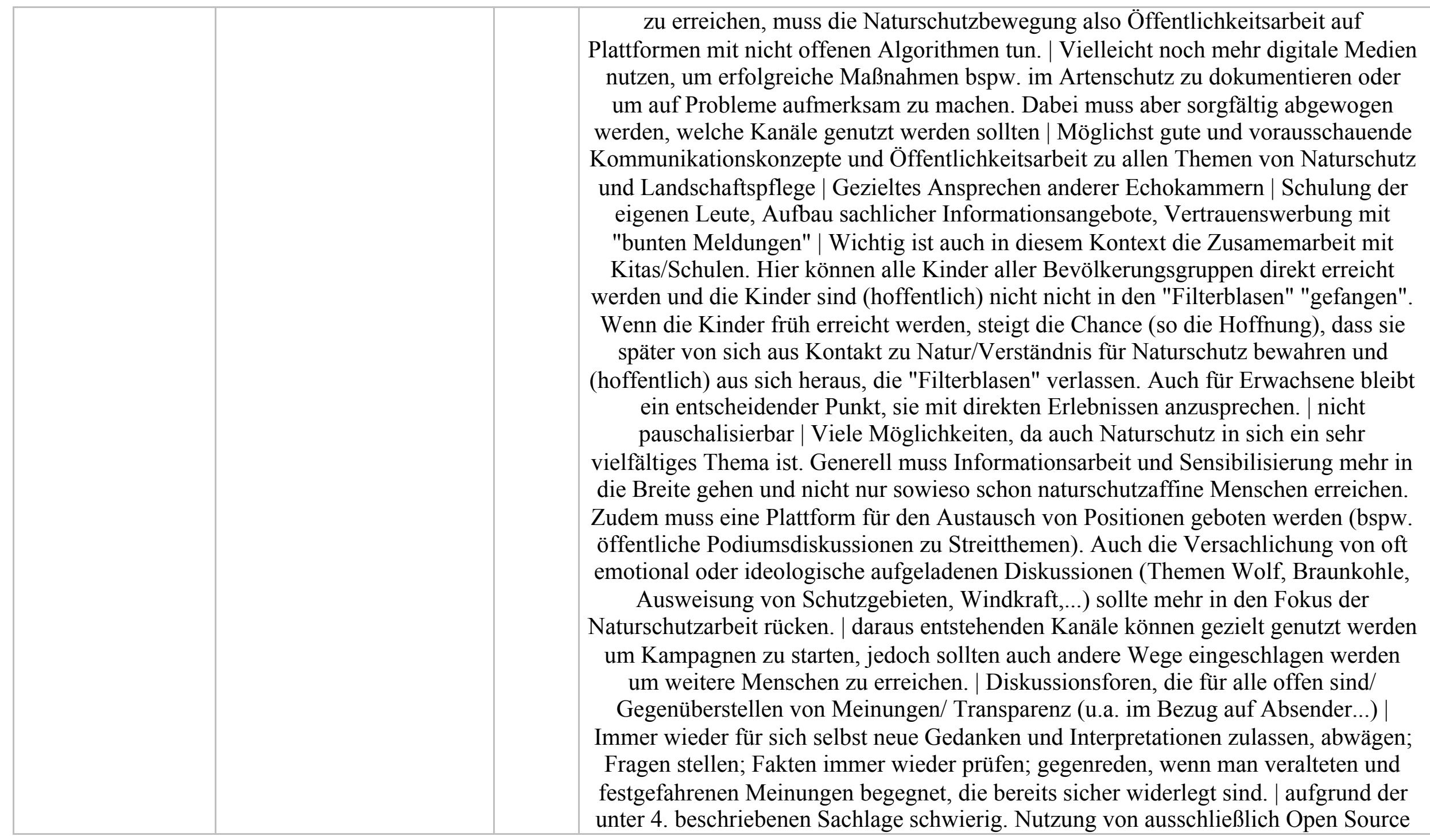




\begin{tabular}{|c|c|c|c|}
\hline & & & $\begin{array}{l}\text { Lösungen führt wieder zu Filterblasen innerhalb der Naturschutzgemeinde, wenn auch } \\
\text { Filterblasen durch Algorithmen (insb. durch Werbung) nicht verstärkt werden | im } \\
\text { Naturschutz-Diskurs Open Source Lösungen präferieren, aber trotzdem auch die nicht } \\
\text { offenen Plattformen nutzen, um die breite Öffentlichkeit zu erreichen. }\end{array}$ \\
\hline $\begin{array}{l}\text { Echo chambers and } \\
\text { filter bubbles are of } \\
\text { relevance in the } \\
\text { communication of } \\
\text { nature conservation } \\
\text { topics. }\end{array}$ & $\begin{array}{l}\text { Echo chambers and filter } \\
\text { bubbles can reinforce } \\
\text { views on nature } \\
\text { conservation topics. }\end{array}$ & 9 & $\begin{array}{l}\text { verstärkt es die Infos in der eigenen Community | Verstärkung von Vorurteilen } \\
\text { bestimmter Interessengruppen | Da sie in beide Richtungen (Pro und Contra } \\
\text { Naturschutz) radikalisieren können. Meinungen werden immer extremer | Gleichzeitig } \\
\text { ist der Austausch unter "Gleichgesinnten" wichtig um das eigene Engagement zu } \\
\text { bestärken und die Motivation für Naturschutzarbeit aufrecht zu erhalten | } \\
\text { Confirmation Bias: Wir neigen wir dazu, Informationen zu bevorzugen, die mit den }\end{array}$ \\
\hline
\end{tabular}




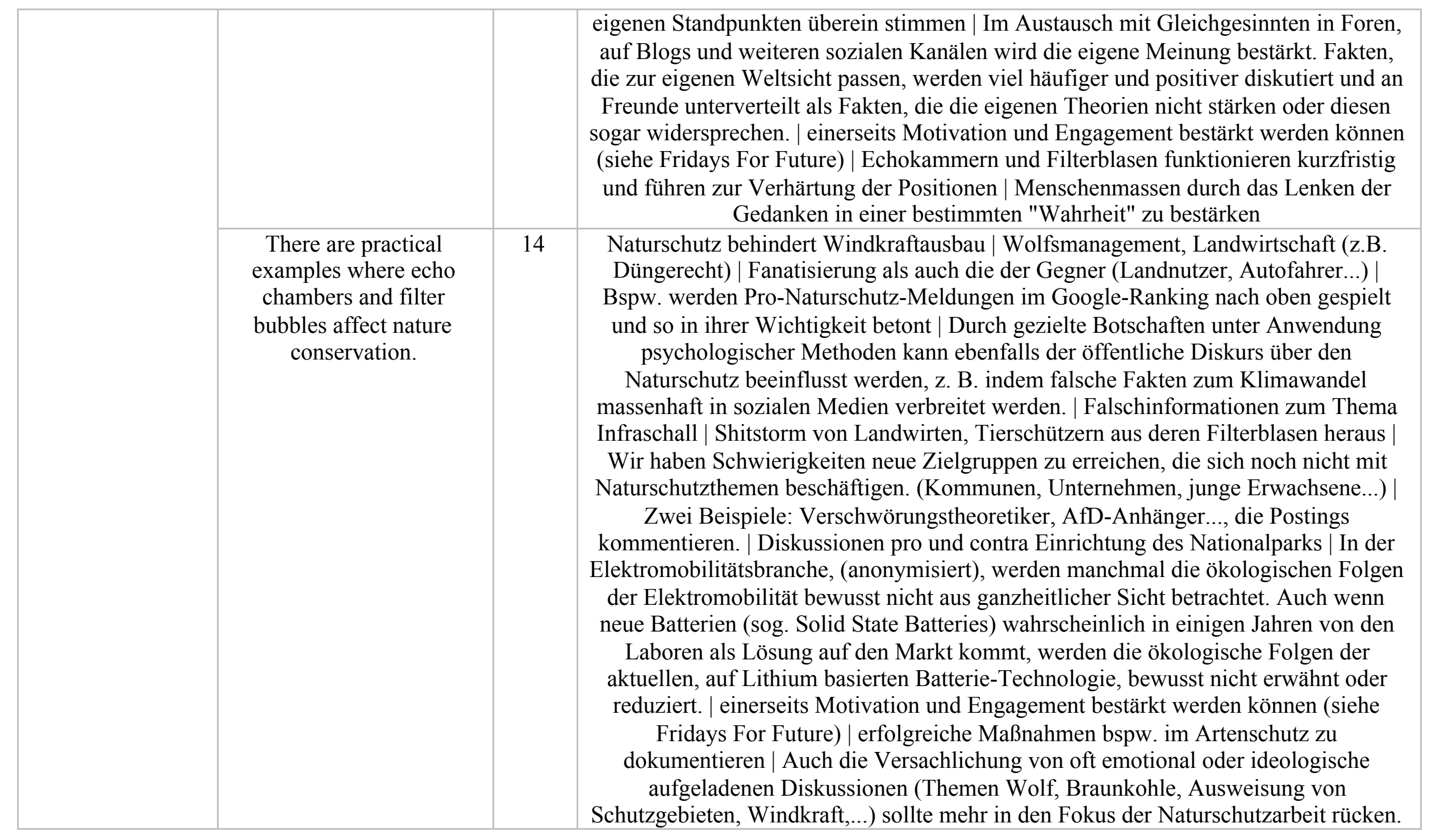




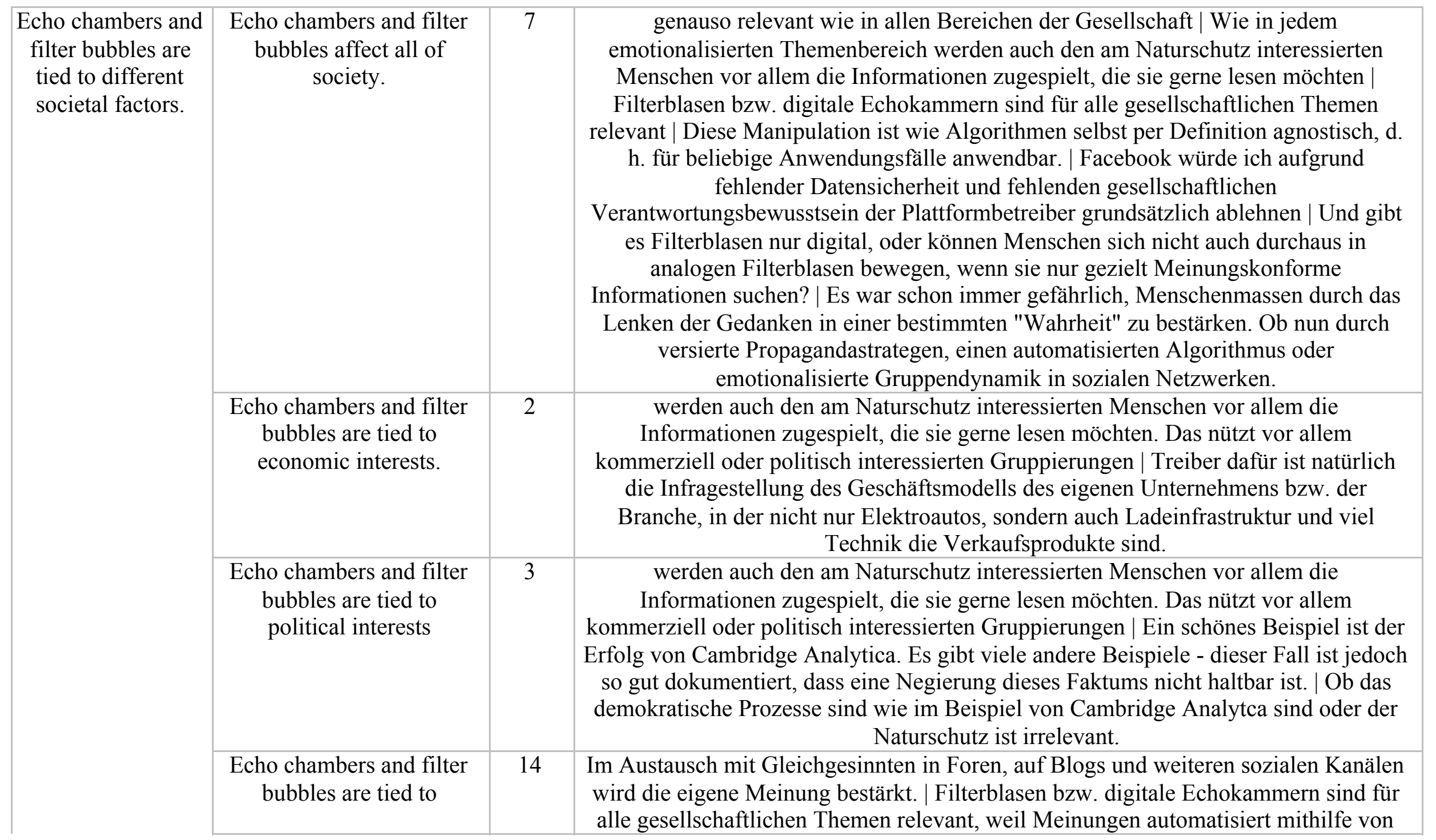


technological and digital factors.
Algorithmen erzeugt werden können | Durch gezielte Botschaften unter Anwendung psychologischer Methoden kann ebenfalls der öffentliche Diskurs über den Naturschutz beeinflusst werden, z. B. indem falsche Fakten zum Klimawandel massenhaft in sozialen Medien verbreitet werden. | arbeite unter anderem mit Social Media | Diskussionen pro und contra Einrichtung des Nationalparks auch in den sozialen Netzen | In den sozialen Medien dieser Branche werden daher bewusst

Botschaften für die saubere Elektromobilität verbreitet, sowie kritische Botschaften nicht auf z. B. Twitter geteilt. Algorithmen verstärken diesen Pfad, wordurch

klassische Filterblasen entstehen, da Algorithmen in den eigenen Online-Netzwerken Informationen platzieren, die dieser Meinung entsprechen. | Der (anonymisiert) ist zudem sehr wenig in social media unterwegs. Z. Zt. nur bei Twitter. | eine breite Öffentlichkeit erreicht werden soll, die zu hohem Anteil Plattformen nutzt, die auf nicht kontrollierbaren Algorithmen basieren. Denn diese sind nicht Open Source, d. h. die Technologie dahinter (der "Source Code") ist nicht open, also nicht öffentlich und damit nicht einsehbar oder änderbar. Leider verwenden allerdings der Großteil der Menschen dieses sog. proprietären Algorithmen/Dienste, wie an diesem Google Sheet auch zu sehen ist ;) Dadurch haben wir als Gesellschaft kaum noch Souveränität (Kontrolle, Einfluss) über Algorithmen im Internet. Um die breite Öffentlichkeit zu erreichen, muss die Naturschutzbewegung also Öffentlichkeitsarbeit auf Plattformen mit nicht offenen Algorithmen tun. | Dabei muss aber sorgfältig abgewogen werden, welche Kanäle genutzt werden sollten. Bspw. Kommunikation über Facebook würde ich aufgrund fehlender Datensicherheit und fehlenden gesellschaftlichen Verantwortungsbewusstsein der Plattformbetreiber grundsätzlich ablehnen. | Zudem muss eine Plattform für den Austausch von Positionen geboten werden (bspw. öffentliche Podiumsdiskussionen zu Streitthemen). | Diskussionsforen, die für alle offen sind/ Gegenüberstellen von Meinungen/ Transparenz (u.a. im Bezug auf

Absender...) | Nutzung von ausschließlich Open Source Lösungen führt wieder zu Filterblasen innerhalb der Naturschutzgemeinde, wenn auch Filterblasen durch Algorithmen (insb. durch Werbung) nicht verstärkt werden. | IMHO sollte man im Naturschutz-Diskurs Open Source Lösungen präferieren, aber trotzdem auch die nicht 
offenen Plattformen nutzen, um die breite Öffentlichkeit zu erreichen. | Es war schon immer gefährlich, Menschenmassen durch das Lenken der Gedanken in einer bestimmten "Wahrheit" zu bestärken. Ob nun durch versierte Propagandastrategen, einen automatisierten Algorithmus oder emotionalisierte Gruppendynamik in sozialen Netzwerken. 